\title{
Current Research in Photosynthesis
}

\section{Volume IV}

Proceedings of the VIIIth International Conference on Photosynthesis Stockholm, Sweden, August 6-11, 1989

edited by

\section{BALTSCHEFFSKY}

Department of Biochemistry.

University of Stockholm,

Stockholm. Sweden 


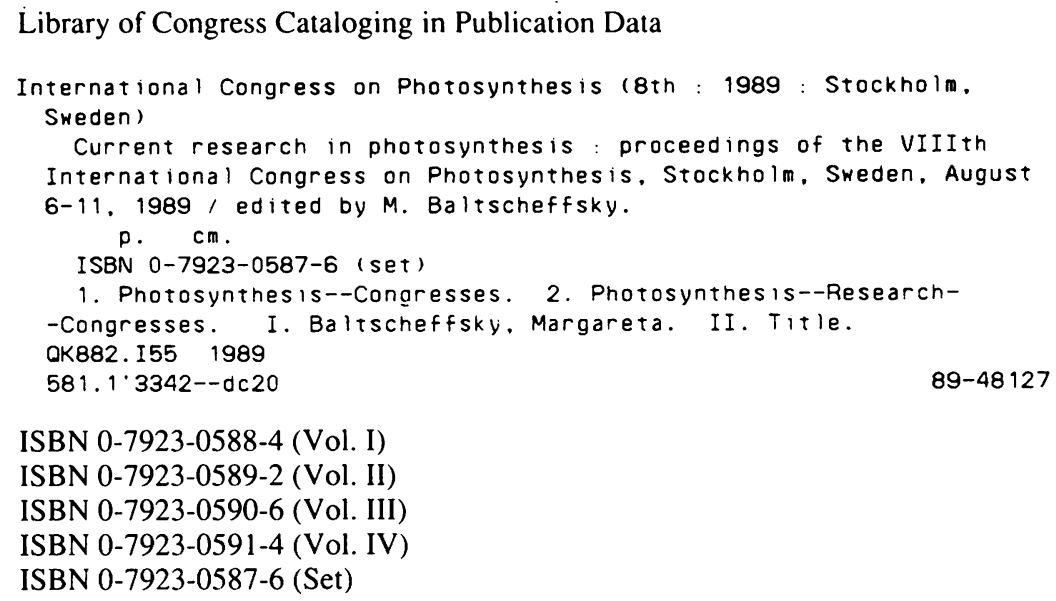

Published by Kluwer Academic Publishers,

P.O. Box 17, 3300 AA Dordrecht, The Netherlands.

Kluwer Academic Publishers incorporates the publishing programmes of D. Reidel, Martinus Nijhoff, Dr W. Junk and MTP Press.

Sold and distributed in the U.S.A. and Canada by Kluwer Academic Publishers, 101 Philip Drive, Norwell, MA 02061, U.S.A.

In all other countries, sold and distributed by Kluwer Academic Publishers Group, P.O. Box 322, 3300 AH Dordrecht, The Netherlands.

Printed on acid-free paper

\section{All Rights Reserved}

(C) 1990 by Kluwer Academic Publishers

No part of the material protected by this copyright notice may be reproduced or utilized in any form or by any means, electronic or mechanical including photocopying, recording, or by any information storage and retrieval system, without written permission from the copyright owner.

Printed in The Netherlands 


\section{GENERAL CONTENTS}

\section{Volume I}

1. Reaction Centers From Purple Bacteria

2. Photosystem II 209

3. $\mathrm{O}_{2}$ Evolution $\quad 675$

Volume II

4. Prokaryotic Antennae Systems $\quad 1$

5. Eukaryotic Antennae Systems 209

6. Photoinhibition 349

7. Photosystem I 523

8. Structure, Function and Dynamics of the Thylakoid Membrane 715

Volume III

9. $\mathrm{H}^{+}$ATPases 1

10. Cytochrome $\mathrm{B} / \mathrm{C}_{1}$ and $\mathrm{B} / \mathrm{F}$ Complexes 221

11. Rubisco 323

12. Structure, Function and Regulation of Photosynthetic Genes 423

13. Biosynthesis and Assembly of the Photosynthetic Apparatus 653

$\begin{array}{ll}\text { 14. Chloroplast Differentiation } & 827\end{array}$

Volume IV

15. Respiration and Photosynthesis 1

16. Regulation of Chloroplast Metabolism 111

17. Adaptation Mechanisms 291

18. $\mathrm{CO}_{2}$ Concentrating Mechanisms 433

19. Stress and Photosynthesis $\quad 549$

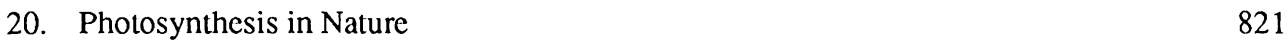





\section{CONTENTS TO VOLUME IV}

General Contents $\quad$ V

Contents Volume IV VII

Preface $\quad$ XXI

Acknowledgements $\quad$ XXIII

Organizing Committees $\quad$ XXV

Opening Speech $\quad$ XXVII

15. Respiration and Photosynthesis

Transfer of Redox Equivalents Between Subcellular Compartments of a Leaf Cell 1 H.W. Heldt, D. Heineke, R. Heupel, S. Krömer, B. Riens

Photorespiratory Dependent Leaf Mitochondrial ATP Production 9

P. Gardeström, B. Wigge

Photorespiratory Metabolism and Pigment Changes in Photorespiration Mutants

P.J. Lea, R.D. Blackwell, K.J. Lewis, A.J. Young, G. Britton

The pH Stat of Chloroplasts in Relation to Ribulose Bisphosphate Carboxylase Activity and Inorganic Nitrogen and Sulphate Assimilation

I.R. Kennedy

The Light Response of $\mathrm{CO}_{2}$ Gas Exchange and Internal $\mathrm{CO}_{2}$ Concentration Separated for the Upper and Lower Side of a Maize Leaf

W. Postl, H.R. Bolhar-Nordenkampf

Using Whole Plant Net $\mathrm{CO}_{2}$ Exchange Data for Predicting Productivity of Greenhouse Roses

J. Jiao, M.J. Tsujita, B. Grodzinski

Photosynthesis Dark Respiration and Plant Production in Nicotiana tabacum Genotypes

Derived from Haploids Selected by Low $\mathrm{CO}_{2}$ Survival

E. Delgado, J. Azcon-Bieto, H. Medrano

ATP Deprivation Induces State I to State II Transition in the Dark in Chlamydomonas reinhardtii

P. Gans, L. Bulte, F. Rebeille, F.-A. Wollman

Effect of the Salinity on the ATPase Activity (CF1, F1) Electron Transport in Photosystems I, II and Respiratory Chain in Medicago sativa and Amaranthus hypochondriacus M.S. González, M.J. Vázquez, Z.R. Quintanar, G.R. Velasco

Interaction of the Photosynthetic and Respiratory Electron Transport Chains of Rhodobacter sphaeroides

S. Brown, J.P. Armitage 
The Effect of Low Intensity Blue Light on the Rates of Respiration and Photosynthesis,

Composition and Growth of Lemna gibba

J. Gale, G. Granot, M. Zeroni, J. Reubeni

Glycine Oxidation in Green and Etiolated Tissue

P. Gardeström, D. Henricson, B. Wigge

Upshift of Light Intensity on Synechocystis 6714 Causes Increases in Glycogen, Respiration, and P700 Reduction

J. Myers

Does NADH Availability Limit Nitrate Reduction in Wheat Genotypes?

M.Z. Abdin, P.A. Kumar, Y.P. Abrol

The Effect of $\mathrm{H}_{2} \mathrm{O}_{2}$ on the Photosynthetic Biochemistry of Pisum sativum

L. Ford, N.W. Pammenter, A.M. Amory, C.F. Cresswell

Use of Computer Simulation and Non-Linear Regression in Photosynthetic Studies A.M. Amory, N.W. Pammenter, C.F. Cresswell

Photosynthesis, Photorespiration and Partitioning in Leaflets, Stipules and Tendrils of Pisum sativum

R. Côté, B. Grodzinski

Effects of Glucose Feeding on Photoautotrophic Cell Suspension of Dianthus caryophillus M.H. Avelange, F. Sarrey, F. Rebeille

Affinity Labeling of Phosphoribulokinase by Adenosine Polyphosphopyridoxals H.M. Miziorko, C.A. Brodt

Catalase in an Aerobic Photosynthetic Bacterium, Erythrobacter sp. OCH 114 M. Morita, K.-I. Takamiya

Immunocytochemical Localization of the Electron Carrier Proteins FerredoxinNADP ${ }^{+}$Oxidoreductase and Cytochrome $c 553$ in the $\mathrm{N}_{2}$-Fixing Cyanobacterium Anabaena variabilis

A. Serrano, P. Gimenez, S. Scherer, P. Böger

A Soluble Polysaccharide Fraction from Higher Plants: A Possible Physiological Substrate of the Cytosolic Phosphorylase Isozyme

Y. Yang, B. Greve, M. Steup, E.W. Weiler

The Effect of Photosynthesis on Different Steps of Dark Respiration

N. Mamushina, H. Zubkova, L. Filippova

Photosynthesis as a Thermal Process

G.G. Komissarov

\section{Regulation of Chloroplast Metabolism}

Regulation of Light Harvesting by Metabolic Events

P. Horton

Regulation of Ribulose Bisphosphate Carboxylase Activity by Rubisco Activase: Aspects of the Mechanism

A.R. Portis, Jr., S.P. Robinson, R. McC. Lilley

Redox-Regulation of Chloroplast Enzymes: Mechanism and Physiological Significance

R. Scheibe

Light/Dark-Regulation of $\mathrm{C}_{4}$-Photosynthesis Enzymes by Reversible Phosphorylation

R. Chollet, R.J.A. Budde, J.-A. Jiao, C.A. Roeske 
Purification and Characterization of Phosphoribulokinase from N2 Fixing Cyanobacterium Nostoc muscorum

D.V. Amla

Molecular Models of 3-Dimensional Structures of Chloroplast and Cytoplasmic Phosphoglycerate Kinase from Wheat

E.M. McMorrow, B.J. Sutton, J.W. Bradbeer

The Regulation of Synthesis of Chloroplastic and Cytosolic Isoenzymes of Phosphoglycerate Kinase in Barley

N. Shah, J.W. Bradbeer

A Comparison of the Regulation of Yeast Phosphoglycerate Kinase with the Isoenzymes of Barley Chloroplast and Cytosol

E.M. McMorrow, J.W. Bradbeer, P.O. Montiel-Canobra, M. Larsson-Raźnikiewicz

Relationship Between the Primary Structure of Ferredoxin and Thioredoxin and Their Reactivity

J.P. Jacquot, F. de Lamotte, M. Miginiac-Maslow, R. Peyronnet, J.B. Peyre, E. Wollman, P. Decottignies

In Vivo Synthesis and Immunological Relationship of Thioredoxin $f$ from Pea and Spinach A. Chueca, M. Sahrawy, J.L. Carrasco, J.L. Ramos, J.J. Lázaro, R. Hermoso, J. López Gorgé

Primary Structures of Regulatory Proteins of the Ferredoxin-Thioredoxin System of Spinach Chloroplasts

R. Schürmann, L. Gardet-Salvi, M. Kamo, K. Yano, A. Tsugita

Regulation of Photosynthesis: Photosynthetic Control and Thioredoxin-Dependent Enzyme Regulation

D. Lechtenberg, B. Voss, E. Weis

Function of Two Dissimilar Thioredoxins in the Cyanobacterium, Anabaena sp. 7120 F.K. Gleason

Effect of Heterotrophic Growth on the Thioredoxins of Wild Type and y-1 Chlamydomonas reinhardtii

H.C. Huppe, B.B. Buchanan, J.-P. Jacquot

Regulation of Pyruvate-Orthophosphate Dikinase from Maize Leaves. Magnesium-Dependent Dimer-Tetramer Interconversion

H. Nakamoto

Separation and Characterization of Fructose-1,6-Bisphosphatases and Sedoheptulose-1.7-

Bisphosphatases from Leaves of Pisum sativum $\mathrm{L}$.

D. Nothnagel, J. Hoffstädt, E. Latzko

Control of Stromal Fructose 1.6 Bisphosphatase and Sedoheptulose 1.7 Bisphosphatase by Metabolite Levels

D. Schimkat, D. Heineke, H.W. Heldt

Interaction of Chloroplast Fructose-1.6-Bisphosphatase with Micelles of Triton X-114

G. Prat-Gay, R. Rodriguez-Suarez, R.A. Wolosiuk

The in vivo Functioning Forms of Ribulose 1,5-Bisphosphate Carboxylase/Oxygenase in Plants

A. Yokota, T. Taira, H. Usuda, S. Kitaoka

Structural Analysis of the Triose Phosphate-3-Phosphoglycerate-Phosphate Translocator from Spinach Chloroplasts

U.I. Flügge, K. Fischer, A. Gross 
Binding of the Lipophilic Tertiary Amine and 'Selective' Uncoupler Dibucaine to

Thylakoid Membranes

G. Günther, H. Laasch

Localized Proton Domains in pH-Dependent Control of Photosynthetic Electron Transport under the Influence of Lipophilic Tertiary Amines

A. Janowitz, G. Günther, H. Laasch

Oscillations of Photosynthesis in Intact Isolated Pea Chloroplasts in the Presence of DCMU and Antimycin A

S. Veljović, Z.G. Cerovic, M. Plesničar

Photosynthetic Metabolism in Barley Leaves Infected with Powdery Mildew J. Scholes, P. Lee, P. Horton, D. Lewis

The Relationship Between the Development of Haustoria of Erysiphe graminis and the Energy Status of Leaves

D.P. Wright, J.D. Scholes, P. Horton, B.C. Baldwin, M.C. Shephard

Synthesis of Alanine from 3-Phosphoglycerate by Intact Bundle Sheath Cells of Zea Mays E.M. Valle, H.W. Heldt

The Principal Scheme of Photosynthetic Carbon Conversion in Cells of Isoprenereleasing Plants

G.A. Sanadze

The Enhancement Effect of Isoprene Evolution by Poplar Leaves

D.I. Baazov, G.A. Sanadze

Regulation of NADP-Malate Dehydrogenase Light-Activation by the Reducing Power.

I. Functional Studies

M. Miginiac-Maslow, P. Decottignies, J.-P. Jacquot, P. Gadal

Regulation of NADP-Malate Dehydrogenase Light-Activation by the Reducing Power.

II. Structural Studies

P. Decottignies, J.-M. Schmittrer, M. Miginiac-Maslow, P. Le Maréchal, J.-P. Jacquot, P. Gadal

Light Activation of Membrane-Bound Fructose-1.6-Bisphosphatase from Pea Leaf Chloroplasts

J.J. Lázaro, A.R. Andrés, A. Chueca, R. Hermoso, J. López Gorgé

How Can the $\mathrm{C}_{4}$ Stromal System Sense Differences in Light Intensity to Adjust Its Activities to the Overall Flux?

H. Usuda

The Relationship Between the Efficiencies of Photosystems I and II and the Control of Electron Transport

J. Harbinson, B. Genty, C.H. Foyer, N.R. Baker

Differential Diumal Carbon Exchange and Photoinhibition in a psbA Plastid Gene

Chronomutant of Brassica napus

J. Dekker, R. Burmester

Photosynthesis and Chlorophyll Fluorescence Quenching in Aging Leaves of Three

Sunflower (Helianthus annuus L.) Genotypes

D. Saftic, M. Plesnicar

Developmental Variation in Aspartate-Family Amino Acid Biosynthesis by Isolated

Chloroplasts

W.R. Mills, S.F. Capo, S.A. Bergh, C.B. Lassiter 
Activities of Carbondioxide Fixing Enzymes in Maize Tissue Cultures in Comparison to Young Seedlings

A. Kumar, S. Roy, K.-H. Neumann

Measurement of Photochemical and Non-Photochemical Quenching: Correction for Turnover of PS2 During Steady-State Photosynthesis

T. Markgraf, J. Berry

Regulation of $\mathrm{CO}_{2}$ Assimilation During Photoinhibition

M. Dujardyn, C.H. Foyer

Intermediates, Catalytic Components and Light and Dark Regulation of ALA and Chlorophyll Formation in the Green Alga Scenedesmus

D. Dörmemann, V. Breu, K. Kotzabasis, P. Richter, H. Senger

17. Adaptation Mechanisms

Adaptation of Photosystem Stoichiometry in Oxygen-Evolving Thylakoid Membranes

A. Melis

Factors Determining Light Response Characteristics of Leaf Photosynthesis

I. Terashima, A. Takenaka

Physiological Control of Primary Photochemical Energy Conversion in Higher Plants

E. Weis, D. Lechtenberg, A. Krieger

Trans- $\Delta^{3}$-Hexadecenoic Acid, LHC II and Low Temperature Development in Herbaceous Plants

N.P.A. Huner, M. Krol, S. Boese, V. Hurry, J.P. Williams, G. Oquist

Chromatic Adaptation in Porphyridium cruentum Expressed in the Distribution of Excitation Energy and in the Thylakoid High-Energy Fluorescence Quenching

O. Canaani, S. Driesenaar, S. Malkin, E. Gantt

The Involvement of LHC 2 Phosphorylation in the Adaptation of Higher Plants ot Changing Light Intensities and Some Results on the Regulation of LHC 2 Phosphorylation in vivo H. Dau, O. Canaani

Thylakoid Protein Phosphorylation in an Algae with Chlorophyll A/C/Fucoxanthin Light Harvesting Antenna

P. Gibbs, J. Biggins

Characterisation and Purification of Polypeptides Undergoing Light-Dependent Phosphorylation in the Cyanobacterium Synechococcus 6301 M. Harrison, J.F. Allen

Functional Analysis of the Photosynthetic Apparatus in a Chlorophyll-Deficient Mutant of Cowpea

D. Habash, B. Genty, N.R. Baker

Slow Fluorescence Transients in Photosynthetic Bacteria

I. Setlik, M. Waldburger-Schlapp, R. Bachofen

The Influence of Light Itensity on the Organization of the Photosynthetic Apparatus

Rhodopseudomonas Palustris Strain AB

Y.E. Erokhin, Z.K. Makhneva, I.R. Prokhorenko

Effects of Growth Irradiance on the Photosynthetic Apparatus of the Red Alga Porphyridium cruentum

F.X. Cunningham, Jr., R.J. Dennenberg, L. Mustardy, P.A. Jursinic, E. Gantt 
Red Light Enhances $\mathrm{Q}_{\mathrm{A}}$ Relative to $\mathrm{P}_{700}$ and Phycobilisomes in the Red Alga Porphyridium cruentum

F.X. Cunningham, Jr., R.J. Dennenberg, L. Mustardy, P.A. Jursinic, E. Gantt

Regulation of LHC II mRNA Levels During Photoadaptation in Dunaliella tertiolecta (Chlorophyceae)

J. LaRoche, A. Mortain-Bertrand, J. Bennett, P.G. Falkowski

Fluorescence Responses on Step Changes in Irradiance by Plants from Different Light Habitats

G. Johnson, P. Horton, J. Scholes, P. Grime

The Relationship Between the Relative Quantum Efficiencies of Photosystems in Leaves.

Efficiency of PS2 in Relation to Non-Photochemical Fluorescence Quenching

B. Genty, J. Harbinson, J.M. Briantais, N.R. Baker

Adaptation of the Light Harvesting Apparatus to Shade in Silene dioica (L.): Relationship Between PSI and PSII Efficiences M. McKiernan, B. Genty, N.R. Baker

Different Amino Acid Exchanges in the D1 Protein Cause Different Degrees of Shade Type Appearance in Herbicide Tolerant Anacystis

F. Koenig

Characterization of the Light Dependent Regulation of the Apparent Quantum Yield of PSI A.M. Rehm, A. Ried

Alteration in Thylakoid Composition and Structure of Brassica rapa Ssp. Oleifera During Ageing in High and Low Light

A. Nurmi

Changes in Thylakoid Surface Area When Shade Acclimated Helianthus annuus L. Chloroplasts Are Exposed to High P.F.D.

W.R. Fagerberg

Effect of Cold-Hardening on the Quantum Yield of Spinach Leaves K.J. van Wijk, P.R. van Hasselt

Environmental and Hormonal Dependence of Induction of Crassulacean Acid Metabolism in Mesembryanthemum crystallinum

G. Edwards, S.-H. Cheng, C. Chu, M. Ku

Control of Oxidative Phosphorylation in the Adaptation of Medicago sativa, Phaseolus aureus and Phaseolus vulgaris to Salinity

M.S. González, Z.R. Quintanar, M.J. Vázquez, G.R. Velasco

Salinity and the Regulation of Pyruvate Pi Dikinase

D. Moualem-Beno, A. Shomer-Ilan

Nitrogen Deprivation and the Photosynthetic Apparatus of the Green Alga Chlorella fusca M.H. Rieß, I. Damm, L.H. Grimme

Gas Exchange, Chlorophyll a Fluorescence, and Metabolite Levels in Leaves of Trifolium Subterraneum During Long-Term Exposure to Elevated $\mathrm{CO}_{2}$

T. Betsche, F. Morin, F. Cote, F. Gaugain, M. Andre

Chlorophyllous Calli from Psoralea bituminosa L. - Adaptation to Photomixotrophism J. Diamond, A. Casimiro, M.S. Pais

Photosynthesis in Flowers of Petunia Hybrida: Low $\mathrm{CO}_{2}$ Flow and Coordinated Reduction Between Photosynthetic Systems

D. Weiss, A. Shomer-Ilan, A.H. Halevy 
The Reversible Photochemistry of Phycoerythrocyanin

S. Siebzehnrübl, G. Lipp, R. Fischer, H. Scheer

Quantitative Analysis of the Chlorophyll Fluorescence Induction Curve: Facts and Artefacts

S. Mauro, R. Lannoye

Physiologically Active Products of Chloroplast Components Degradation

I.A. Tarchevsky, A.N. Grechkin, S.I. Pankratova, A.U. Yarin, J.E. Andrianova

18. $\mathrm{CO}_{2}$ Concentration Mechanisms

Photosynthetic Inorganic Carbon Transport and Accumulation in Macroalgae

F. Brechignac

Photosynthetic Acclimation to Low Carbon Concentrations in Chlamydomonas reinhardtii

G. Samuelsson, K. Palmqvist, Z. Ramazanov, L.-G. Sundblad

Proteins Synthesized During Induction of the $\mathrm{CO}_{2}$ Concentrating Mechanism in

Chlamydomonas reinhardtii

J.V. Moroney

The Molecular Biology of Carbonic Anhydrase Expression in Chlamydomonas reinhardtii J.R. Coleman

Mutations in the 5' Flanking Region of $r b c \mathrm{~L}$ Inhibit the Growth of Synechococcus PCC7942 in Air-Level of $\mathrm{CO}_{2}$ and Alter the Carboxysome Structure

D. Friedberg, A. Kaplan, R. Ariel, R. Schwarz, E. Sadovnick, M. Kessel, J. Seijffers

Identification of the Genomic Region Which Complements a Temperature-Sensitive High$\mathrm{CO}_{2}$ Requiring Mutant of the Cyanobacterium, Synechococcus PCC7942

E. Suzuki, H. Fukuzawa, T. Abe, S. Miyachi

Molecular Analysis of Mutants of Synechocystis PCC6803 Defective in Inorganic Carbon Transport

T. Ogawa, J.G.K. Williams, T. Omata

Is Carbonic Anhydrase Required for Photosynthesis?

C.A. Roeske, J.M. Widholm, W.L. Orgen

441

Carbonic Anhydrase Activity in Barley Leaves After Treatment with Abscisic Acid and Jasmonic Acid

L.P. Popova, G.N. Lazova

Isolation of Carbonic Anhydrase from the Higher Plant Pisum sativum N. Majeu, J.R. Coleman

Membrane-Bound Carbonic Anhydrase Takes Part in $\mathrm{CO}_{2}$ Concentration in Algae Cells N.A. Pronina, V.E. Semenenko

Chemical Cross-Linking of Periplasmic Carbonic Anhydrase from Chlamydomonas reinhardtii

H.D. Husic

The Role of Carbonic Anhydrase in Regulating Photosynthetic $\mathrm{CO}_{2}$ Fixation in Higher Plants

G. Yuzhu, Z. Zhenlin, G. Minliang, W. Zhong

Expression of a Cyanobacterial Gene Regulated by $\mathrm{CO}_{2}$ Concentration

D. Chamot, J.R. Coleman

Adaptation of Chlamydomonas reinhardtii High $\mathrm{CO}_{2}$-Requiring Mutants to Limiting $\mathrm{CO}_{2}$ M.H. Spalding, K. Suzuki, A.M. Geraghty 
A Phosphoglycolate Phosphatase Mutant of Chlamydomonas reinhardtii

K. Suzuki, L.F. Marek, M.H. Spalding

Selective Inhibition of $\mathrm{CO}_{2}$ Transport in a Cyanobacterium

G.S. Espie, A.G. Miller, D.T. Canvin

$\mathrm{CO}_{2}$ Storage and $\mathrm{CO}_{2}$ Concentrating in Brown Seaweeds. I. Occurrence and Ultrastructure H. Ryberg, L. Axelsson, S. Carlberg, C. Larsson, J. Uusitalo

$\mathrm{CO}_{2}$ Storage and $\mathrm{CO}_{2}$ Concentrating in Brown Seaweeds. II. Function in Gas Phase J. Uusitalo, L. Axelsson, S. Carlberg, C. Larsson, H. Ryberg

$\mathrm{CO}_{2}$ Storage and $\mathrm{CO}_{2}$ Concentrating in Brown Seaweeds. III. A Tentative Working Model

L. Axelsson, S. Carlberg, C. Larsson, H. Ryberg, J. Uusitalo

Inducible $\mathrm{CO}_{2}$ Concentrating Mechanisms in Green Seaweeds. I. Taxinomical and Physiological Aspects

S. Carlberg, L. Axelsson, C. Larsson, H. Ryberg, J. Uusitalo

Inducible $\mathrm{CO}_{2}$ Concentrating Mechanisms in Green Seaweeds. II. Ecology and Field Observations

C. Larsson, L. Axelsson, S. Carlberg, H. Ryberg, J. Uusitalo

Substrate Binding to NADP-Malic Enzyme from Maize Leaves as Determined by Intrinsic Fluorescence Quenching C.S. Andreo, F.E. Podesta, A.A. Iglesias

The $\mathrm{CO}_{2}$ Concentrating Function of $\mathrm{C}_{4}$ Photosynthesis

R.T. Furbank, C.L.D. Jenkins, M.D. Hatch

Regulation of $\mathrm{CO}_{2}$ Fixation in the CAM Plant Kalanchoe pinnata (L.) Pers. by Cellular Nitrate

T. Balakumar, M. Sivaguru, P. Moorthy, M.R. James, P.R. Anbudurai

19. Stress and Photosynthesis

Effects of Stress on Photosynthesis

T.D. Sharkey, F. Loreto, T.L. Vassey

Nitrate Reduction in Leaves is Coupled to Net Photosynthesis W.M. Kaiser

Analysis of Chill-Induced Depressions of Photosynthesis in Maize

N.R. Baker, G.Y. Nie, A. Ortiz-Lopez, D.R. Ort, S.P. Long

Spatial and Temporal Heterogeneities of Photosynthesis Detected Through Analysis of Chlorophyll-Fluorescence Images of Leaves

K. Raschke, J. Patzke, P.F. Daley, J.A. Berry

Structure and Possible Function of Chloroplast Heat-Shock Proteins and the Effect of Cyclic

Heat-Shock on Plant Morphogenesis and Circadian Rhythmicity

G. Knack, B. Otto, P. Ottersbach, R. Alexander, Z. Liu, K. Kloppstech

Carotenoids and Oxidative Stress

A.J. Young, G. Britton

Analysis of the Mechanisms of Ozone Damage to Photosynthesis in vivo

P.K. Farage, S.P. Long, E. Lechner, N.R. Baker

The Effect of Ozone on Plant Pigments

A. Price, A. Young, P. Beckett, G. Britton, P. Lea 
Effects of $\mathrm{SO}_{2}$ on Photosynthetic Carbon Metabolism in Leaves of Winter Barley (Hordeum vulgare CV. IGRI)

P.O. Montiel-Canobra, J.W. Bradbeer, N.M. Darrall

Influence of Photosynthetic Capacity, Irradiance and $\mathrm{SO}_{2}$ Fumigation on Shoot Growth of Azalea (Rhododendron) Cultivars

D.J. Ballantyne

Simultaneous Measurements of Chlorophyll Fluorescence and $\mathrm{CO}_{2}-\mathrm{Gas}$ Exchange on Spruce under Fumigation with Peroxides

S. Drenkard, J. Maguhn, A. Ziegler-Jöns, D. Knoppik

The Effect of Prolonged Exposure to Air-Borne Pollutants on the Photosynthesis of Douglas

Fir (Pseudotsuga menziesii) Studied with in vivo Chlorophyll Fluorescence

O. van Kooten, L.W.A. van Hove, W.J. Vredenberg

Properties of Selenium-Induced Glutathione Peroxidase in $\mathrm{Low}-\mathrm{CO}_{2}-\mathrm{Grown}$ Chlamydomonas reinhardtii

S. Shigeoka, T. Takeda, T. Hanaoka, A. Yokota, S. Kitaoka, Y. Iizuka

Molecular Properties of Ascorbate Peroxidase from Tea Leaves

G.-X. Chen, K. Asada

Recovery of Photosynthesis in Winter Stressed Scots Pine

C. Ottander, G. Öquist

Chilling-Induced Alterations in the Photosynthetic Capacity of Chilling-Tolerant and Chilling-Sensitive Cultivars of Zea Mays

C.S. Ting, T.G. Owens, D.W. Wolfe

Photoinhibition and Recovery in Isolated Mesophyll Cells of Hardened and Non-Hardened Rye

L. Lapointe, N. Huner

Photoinhibition and Recovery of Photosynthesis in Antarctic Bryophytes under Field Conditions

A. Post, E. Adamson, H. Adamson

Photosynthesis in Grimmia antarctici, An Endemic Antarctic Bryophyte, is Limited by Carbon Dioxide

E. Adamson, A. Post, H. Adamson

Photosynthetic Characterization of Spinach Developed at Cold Hardening and Non

Hardening Temperatures

S.R. Boese, N.P.A. Huner

Frost Resistance of Wheat and CHL a in vivo Fluorescence Induction Kinetics

L. Shiqing, Y. Dianan, Z. Jide, L. Tongzhu, T. Chongqing, L. Shiqing, K. Tingyun

Changes of Photosynthetic Membrane and Cell Resistance of a Leaf of Wheat Seedlings During Temperature Acclimation

A.A. Filimonov, A.A. Virolainen, E.G. Sherudilo, A.F. Titov

Effect of Heat Stress on Intact Wheat Leaves and Its Recovery Studied by Fluorescence Induction Kinetics

R.K. Mishra, G.S. Singhal

Synthesis of Sucrose and Fructans in Wheat Leaves: The Effects of Temperature

C. Paulino, M.C. Arrabaça

The Effect of Temperature on Photosynthesis and Amounts and Transport of Assimilate in

Sunflower and Rape

M.J. Paul, D.W. Lawlor 
Effects of Low Temperature on Chlorophyll Protein Complexes and Regulation Capacity of Excitation Energy Distribution in Chloroplast Membrane of Cucumber

C.H. Xu, F.H. Zhao, K.B. Wang, D.H. Yang, Y.L. Dai

Genetic Variation and Diversity of Low Temperature Induced Damages in Maize Seedlings as Assessed by Chlorophyll Fluorescence Induction Curves

M.-F. Scharll, R. Lannoye, S. Mauro

The Effects of Low Temperature on Activities of Carbon Metabolism Enzymes in Zea mays L. Seedlings M.R. Hull, S.P. Long, C.R. Raines

Chill-Induced Modifications to the Relationship Between Thylakoid Protein Phosphorylation and Energy Distribution ot Photosystem 2 in Maize J. Val, N.R. Baker

Chilling Stress and Active-Oxygen Enzymes in Zea mays and Zea diploperennis L.S. Jahnke, M.R. Hull, S.P. Long

Low Temperature Perturbation of Thylakoid Protein Metabolism During Maize Leaf Development G.Y. Nie, N.R. Baker

Perturbation of the Maize Light-Harvesting Apparatus by Chilling D.A. Campbell, D.B. Hayden, L.B. Johnson, N.R. Baker

Effects of Fire on Photosynthesis and Transpiration in a Mediterranean Ecosystem I. Fleck, F.J. Iñiguez, C. Diaz, M. Pascual

Protective Effect of Putrescine and Spermidine on the Thylakoid Membrane Activity After High Temperature Treatment I.T. Yordanov, V. Goltsev, L. Kruleva

Two Sites of Heat-Induced Damage to Photosystem II D.W. Becker, G. Bain, J. Norman, M. Moholt-Siebert

Light Regulation of the $22 \mathrm{kd}$ Heat-Shock Protein in Chlamydomonas reinhardtii

Responses of Some Photosynthetic Parameters in $\mathrm{C}_{3}$ and $\mathrm{C}_{4}$ Crop Plants under Water Deficit M. Castrillo, D. Fernández, A.M. Calcagno, I. Trujillo

A Gas Exchange Procedure to Evaluate Non Uniform Stomatal Closure Effects in Single Mesophyte Evergreen Leaves Under High VPD G. Bongi

Does Air Relative Humidity During Growth Condition Photosynthetic Characteristics of Coffee Leaf? M.A. Nunes, P.S. Rijo

The Effect of Drought on Chlorophyll Fluorescence in Two Maize Lines L. Jovanovic, V. Janjic, S. Veljovic

Drought Effect on Photosynthesis and Plant Production of Two Contrasting Trifolium Cultivars

J. Vadell, C. Cabot, H. Medrano

Water Stress Effects on Canopy Photosynthesis, Temperature, Transpiration and Shedding of Leaves and Fruit in Cotton

A. Ben-Porath, D.N. Baker, A. Marani 
Water L'se Efficiency in Field-Grown Maize: Effects of Soil Structure

O. Bcthenod, F. Tardieu

An Evaluation of the Effect of Salinity of Photosynthesis

E. Brugnoli, M. Lauteri

Salinity Induced Changes in Leaf Expansion, Photosynthesis and $\mathrm{K}^{+}$Accumulation in

Sunflower

J.M. Cheeseman, S. Basu

Effect of Environmental Stress on Photosynthesis of Isolated Mesophyll Cells from Cowpea Leaves

Z. Plaut, C.M. Grieve, E. Federman

Assimilatory Force in Illuminated Leaves Grown in Sun or Shade or Under Mineral Deficiency

K. Siebke, K.-J. Dietz, U. Heber

Iron Deficiency-Induced Mechanisms of Dissipation of Excess Energy in Higher Plants

A. Abadia, F. Morales, J. Abadia

Low-Iron Stress in the Cyanobacterium Anabaena variabilis

B. Michelsen, M. Miller, R.P. Cox

Violaxanthin Cycle and Fluorescence in Iron-Deficient Maize Leaves J. Val, E. Monge

Acid Resistance and the $\mathrm{CO}_{2}$ - Conductance of the Plasma Membrane of Dunaliella Acidophila

C. Weiss, U. Weis, H. Kugel, H. Gimmler

The $\mathrm{H}^{+}$-Export Capacity of Dunaliella acidophila and the Permeability of the Plasma

Membrane for $\mathrm{H}^{+}$and Weak Acids

H. Gimnmler, M. Bental, H. Degani, M. Avron, U. Pick

Variable Fluorescence for Monitoring Algal Activity in a High Rate Photosynthetic Pond

B. El Hamouri, R. Moundib, R. Berrada

The Effects of Diclofop-Methyl and Methabenzthiazuron on Photosynthetic Parameters in Vicia faba

D. Vidal, M.A. Miranda, F. Rodriguez, E. Simon

Influence of Environmental Stresses on the Photosynthetic Capacity of S-Triazine Susceptible and Resistant Biotype of Solanum nigrum

A. Winterberg, P. Panneels, R. Lannoye

Inhibition of Photosynthesis in Barley (Hordeum vulgare L.) Leaves by Phosphinothricin (Glufosinate). Short and Long-Term Effects

M. Lacuesta, C. González-Murua, A. Muñoz-Rueda, M. Sivak

Effect of the Herbicide SAN 6706 on Pigment Composition in Barley: Measurements Using HPLC

R. Juhler, R.P. Cox

Changes in Photosynthesis of Wheat Plants Infected by Stem Rust

G. Schmittmann, B. Moerschbacher, H.J. Reisener

Drought Effect on the Structural and Functional Characteristics of Photosynthetic Apparatus 801 I.A. Tarchevsky, Y.E. Andrianova, N.I. Safina, E.A. Philippova, D.I. Babuzhina

Isolation and Characterization of Two Isozymes of Superoxide Dismutase from Scots Pine 805

G. Wingsle, P. Gardeström, J.-E. Hällgren 


\section{XVIII}

An Assessment of Ethylene and Carbon Dioxide Exchange in Plants

B. Grodzinski, L. Woodrow

Response of Aging Chloroplasts to UV Radiation

B. Biswal, G. Kulandaivelu

Estimating $\mathrm{SO}_{2}$ Stress by Chlorophyll Fluorescence Measurements with an Active System Used in the Remote Sensing Mode

C. Kliffen

20. Photosynthesis in Nature

Photosynthesis and Field Environmental Productivity Indices

821

P.S. Nobel

Photosynthesis of Plants in Relation to Resource Availability in the Field

E.-D. Schulze

Damage to Photosynthesis During Chilling and Freezing, and Its Significance to the Photosynthetic Productivity of Field Crops

S.P. Long, P.K. Farage, Q. Groome, J.M.N. Macharia, N.R. Baker

Some Factors Limiting Photosynthesis in Nature

Y.-K. Shen

Photosynthetic Capacity to Solve the Carbon Dioxide Problem

S. Leu, A. Michaels

Water Use Efficiency in Potato: Model and Experimental Test of Crop Photosynthesis

O. Bethenod, J.-P. Lhomme, N. Katerji

Photosynthetic Characteristics of the Mangrove, Bruguiera parviflora, (Roxb.) Wright \&

Arn., Under Natural Conditions

D.R. Carter, J.M. Cheeseman, B.F. Clough, C. Lovelock, R.G. Sim, J.E. Ong

Some Physiological Aspects of Paspalum dilatatum Grown Under Field Conditions

J. Marques da Silve, A. Bernardes da Silva, D. Coelho Rebelo, M.C. Arrabaça

Immunogold Localization of Ribulose 1,5-Bisphosphate Carboxylase in Amphibious

Eleocharis Species in Relation to $\mathrm{C}_{3}$ and $\mathrm{C}_{4}$ Photosynthesis

O. Ueno, M. Samejima

Relationships Between Source Leaf Photosynthesis, Export and Grain Filling in Maize

J.-L. Prioul, A. Reyss, N. Schwebel-Dugue, A. Lecharny

The Dependence of Some Photosynthetic Parameters on the Phosphorus Concentration in a Nutrition Solution and Wheat Genotype

S. Zatezalo, Ž. Stanković, M.R. Sarić

Influence of Mineral Nutrition on the Content of Photosynthetic Pigments in Various Wheat Cultivars

M.R. Sarić, Z. Stanković, B. Krstić, S. Zatezalo

Dorsiventrality of the Photosynthetic-Light Response in Naturally Occurring $\mathrm{C}_{3}$ Dicots

T.A. Day, E.H. DeLucia, W.K. Smith

The Effect of Cultivar and Leaf Age on the Content of Photosynthetic Pigments in Wheat

Ž. Stankovic, M.R. Saric, B. Krstic, S. Zatezalo

Effect on Net Carbon Assimilation and Allocation of Assimilates under Elevated $\mathrm{CO}_{2}$ in Mungbean

U.K. Sengupta, A. Sharma 
$\delta^{13} \mathrm{C}$ Analysis to Approach the Mechanism of Varietal Difference of Photosynthetic Rate in Rice Plants

H. Sasaki, M. Samejima, R. Ishii

A New Open Gas-Flow System Configuration for Measurement of Photosynthetic $\mathrm{CO}_{2}$

Response Curve

899

L. Nátr, R. Hák, V. Kotvalt

Impairment of Chloroplast Development and Sink Strength by Blockade of Light in

Chloroembryos of Cyamopsis tetragonoloba (L.) Taub

P. Kaladharan, M. Vivekanandan

Estimation of the Light Limitation of Photosynthesis

H.G. Jones, A. Massacci

The Efficiency of Utilization of Photosynthetically Activa Radiation and Distribution of Assimilates in Sunflow (Helianthus annuus $L$.)

Z. Sakać, T. Cupina

The Relation of Chlorophyll Delayed Fluorescence of Plant with Photosynthesis: Light

Dependence

V. Morgun, N. Znak, S. Doldjikov

Intercepted Irradiance Limits Carbon Assimilation of a Coastal Dune Plant

N.W. Pammenter, V.R. Smith

903

907

Phytoplankton Photosynthesis in the Atlantic Ocean as Measured from a Submersible Pump and Probe Fluorometer in situ

P.G. Falkowski, Z. Kolber

Comparison of Growth of Micro-Algae Nostoc Linckia \& Chlorella sp. in Dilute Culture N. Sen

Effects of Suboptimal Temperature and Light Conditions During Growth on Temperature

Dependent Chlorophyll Fluorescence of Tomato

L.H.J. Janssen, P.R. van Hasselt

Phototrophic Bacteria that form Heat Resistant Endospores

J. Ormerod, T. Nesbakken, Y. Torgersen

Index of Names 
THE REVERSIBLE PHOTOCHEMISTRY OF PHYCOERYTHROCYANIN

SIEBZEHNRÜBL, S., LIPP, G., FISCHER, R., SCHEER, H. Botanisches Institut der Universität, Menzinger Str. 67, D-8000 MÜNCHEN 19, FRG

\section{INTRODUCTION}

Plant and algal biliproteins have two major functions: The phycobiliproteins are light-harvesting pigments for photosynthesis (1); the phytochromes are the photoreceptors of plant photomorphogenesis. Many cyanobacteria also show responses suggesting photoreversibly photochromic pigments as photoreceptors (see $2,3,4,5$ ). The putative pigments have been termed adaptochromes and phycomorphochromes. Isolation attempts (review in 2) resulted in the spectral characterization of at least four different fractions termed phycochromes a-d; but in no case has there been conclusive evidence, that these are the putative photoreceptors.

The absorption spectra of all phycochromes suggest that they are biliproteins, too. These pigments may then combine both functions of light harvesting and photomorphogenesis induction in one molecule. Phycochrome $b$ has indeed been shown to be most likely the $\alpha$-subunit of the antenna pigment phycoerythrocyanin (PEC) (6). PEC is present in several species of cyanobacteria (7). It carries an unusual phycoviolobilin chromophore on its $\alpha$-subunit (Fig. 1) ( 8 ), which is responsible for its photochromic response. Here we want to give further (9) results on the photochemistry of PEC from two cyanobacteria, e.g. Mastigocladus (M). Laminosus and Chroococcidiopsis ( $C h$. ) spec.. We have characterized the photochemistry of the pigment in different states of aggregation, and the mutual interdependence of its phototransformation and aggregation.

\section{MATERIALS AND METHODS}

Phycoerythrocyanin (PEC) of M. laminosus and Ch. spec. were prepared by the method of Füglistaller et al. (10). The subunits of PEC were obtained by isoelectric focusing (11) under anaerobic conditions. Absorption and absorption difference spectra were measured in split beam mode with thermostated cell holders. Irradiation was done in the photometer ( $150 \mathrm{~W}, 1$ ight guide and suitable interference filters). The aggregation state of PEC was studied by sucrose-density gradient centrifugation at $238,000 \mathrm{x} g$ (12). In the reactions relating irradiation with aggregation, a PEC (M. laminosus) stock solution (A $570=0.6 \mathrm{~cm}^{-1}$ ) was irradiated alternately with green and orange light. Before the first and after each subsequent illumination an aliquot $(0.2 \mathrm{ml})$ was applied to the sucrose gradient ( $5 \mathrm{ml}, 7$ to $17 \% \mathrm{w} / \mathrm{w}$ ).

\section{RESULTS AND DISCUSSION}

3.1. Characterization of photochemistry

When PEC or its $\alpha$-subunit isolated from the blue-green algae $M$.

laminosus or $\mathrm{Ch}$. spec. were irradiated either with orange $(600 \mathrm{~nm} ; 575$ 
$\mathrm{nm}$ for Ch. spec.- $\alpha$-subunit) or green light (500 nm), a typical photochemistry was observed. Irradiation with orange light leads to an absorption difference spectrum with a maximum at 502-504 nm and a negative extremum at $565-570 \mathrm{~nm}$. Illuminating the sample with green light reverts the spectrum fully to the original. The amplitudes of the difference spectra are strongly dependent on the state of the pigment (Table 1 ). It is maximum in the presence of $4 \mathrm{M}$ urea, whereas it is lower in the fully denatured pigment ( $8 \mathrm{M}$ urea) and very small in high aggregates and phycobilisomes. Upon addition of increasing amounts of urea, the difference extrema of the reversible reaction remain stationary up to denaturant concentrations of $4 \mathrm{M}$ (Table 1 ). At the same time, the amplitudes increase. At higher urea concentrations, the amplitudes decrease again, and the extrema shift gradually to 510 and $600 \mathrm{~nm}$. Reversible photochemistry is retained up to $8 \mathrm{M}$ urea, when the polypeptide chains are fully unfolded. The photochemistry is very similar in PEC isolated from the two different organisms, e.g. M. laminosus and Ch. spec. Reversible photochemistry is also retained in denatured PEC at low $\mathrm{pH}$.
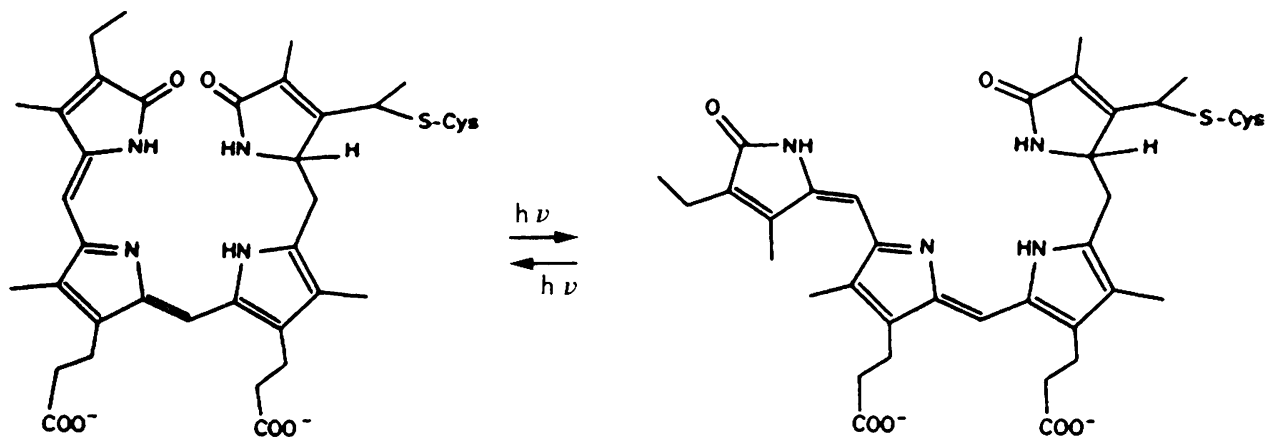

Fig. 1: Structures of phycoviolobilin chromophores in their 10Z,15Z (left) and 10Z,15E-configuration (right). Schematic, native chromophores have extended geometries.

The $\beta$-subunit of PEC shows no reversible photochemical effects. However the two phycocyanobilin chromophors of this subunit are very sensitive against irradiation, and bleach rapidly to colorless product(s) (viz. by $60-70 \%$ within $12 \mathrm{~min}$ ). This rapid bleaching contrasts with the relative stability of the phycocyanin B-subunit (11).

The reversible photochemistry of PEC and its $\alpha$-subunit is probably related to a $Z=E$ isomerisation of the phycoviolobilin chromophore (Fig.1). Of the different chromophore types of phycobiliproteins, it is the only one which shows a reversible photochemistry in its native and denatured state. We suggest that isomerization takes place in the $\alpha$-subunit of PEC at the $\Delta 15$-double bond, similar to the phytochrome primary reaction.

3.2. Interrelations of photochemistry and aggregation Aggregation not only strongly influences the photochemical activity of PEC (Table 1), but the inverse is also true, e.g. pre-irradiation 
Table 1 : Absorption difference extrema and amplitudes of different PEC samples or samples subjected to different pre-treatments.

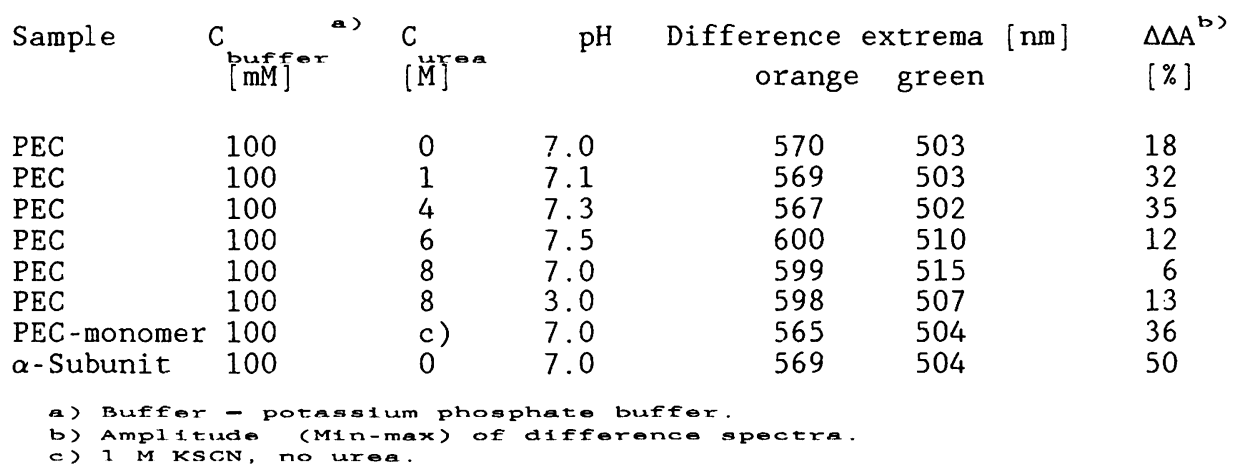

Table 2 : Comparison of photochemistry of PEC between Mastigocladus laminosus and Chroococcidiopsis spec.

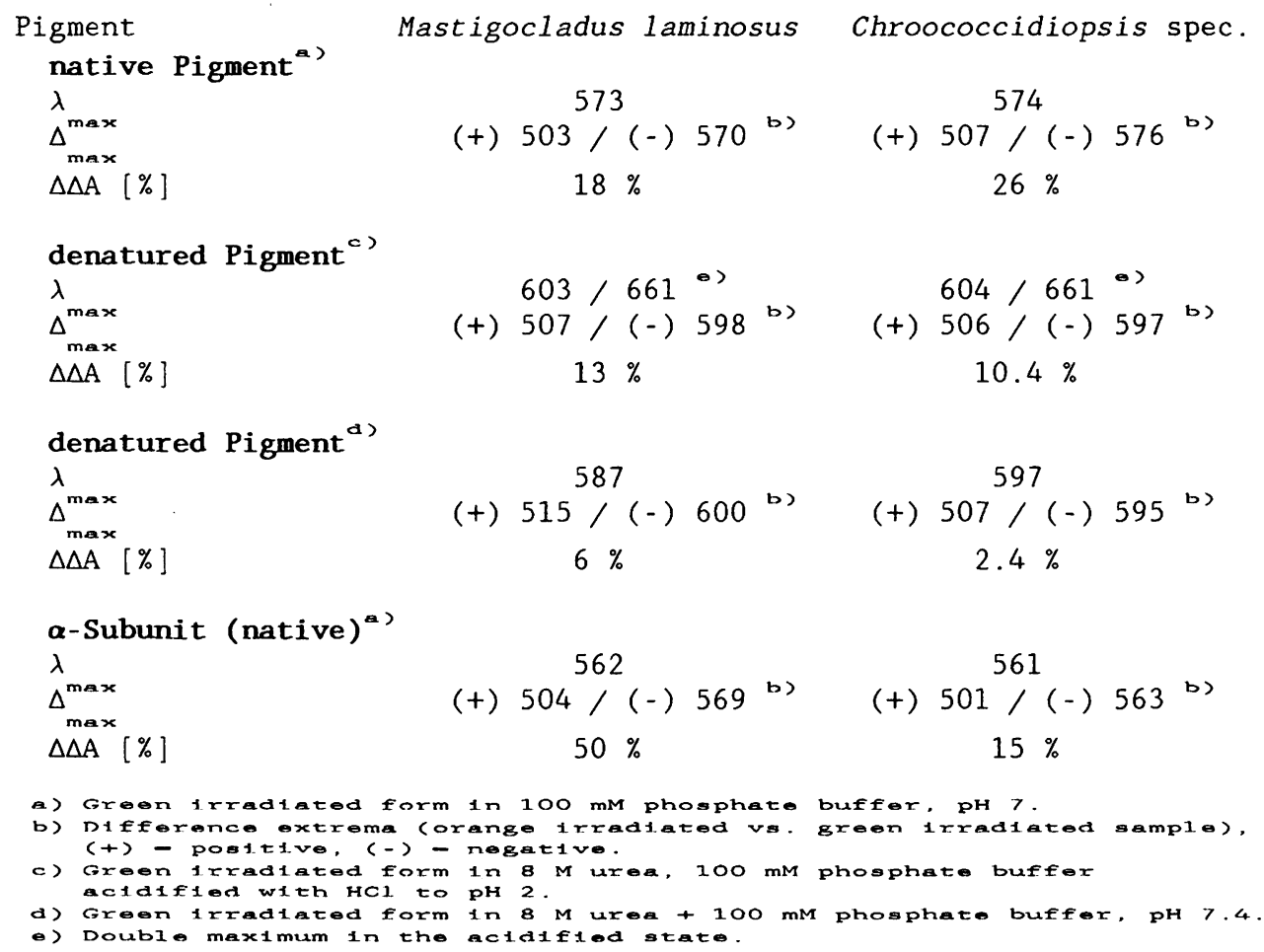




\section{IV.17.424}

with different light qualities influences the aggregation of PEC (9). A sample of PEC was irradiated alternately with orange and green 1 ight. Aliquots of the original sample were then analyzed for aggregate distribution by ultracentrifugation. In every case, the sample is a mixture of mono- and trimeric PEC, but the amount of higher aggregates is always increased after irradiation with green light, and decreased af ter irradiation with orange light. A reversible dissociation as response to different light qualities would principally offer indirect routes for signal transduction, since a direct effect of the phycobiliproteins may be questioned on the basis of the small size of the PEC molecule primarily(?) optimized for light-harvesting.

An indirect route could be based on e.g. photodynamic effects of free biliproteins (13) or the release of linker peptides (14-16).

Acknowledgement: This work was supported by the Deutsche Forschungsgemeinschaft, Bonn (SFB 143).

\section{REFERENCES}

1 MacColl, R. and Guard-Friar, D. (1987) Phycobiliproteins, CRC Press, Boca Raton

2 Björn, L. O. and Björn, G. S. (1980) Photochem. Photobiol. 32, 849-852

3 Bogorad, L. (1975) Ann. Rev. Plant. Physiol. 26, 369-401

4 Scheer, H. (1987) in Progress in Photosynthesis Research (Biggins, J., ed.), Vol.I, pp. 143-149, Martinus Nijhoff Publishers

5 Tandeau de Marsac, N. (1983) Bul1. Inst. Pasteur 81, 201-254

6 Kufer, W. and Björn, G.S. (1989) Physiol. Plant. 75, 389-394

7 Bryant, D.A. (1982) J. Gen. Microbiol. 128, 835-844

8 Bishop, J. E., Rapoport, H., Klotz, A. V., Chan, C. F., Glazer, A. N., Füglistaller, P. and Zuber, H. (1987) J. Am. Chem. Soc. 109, 875-881

9 Siebzehnrübl, S., Fischer, R., Kufer, W. and Scheer H. (1989) Photochem. Photobiol. 49, 753-761

10 Füglistaller, P., Widmer, H., Sidler, W., Frank, G. and Zuber H. (1981) Arch. Microbiol. 129, 268-274

11 Schmidt, G., Siebzehnrübl, S., Fischer, R. and Scheer, H. (1988) in Photosynthetic Light-Harvesting Systems. Organization and Function (Scheer, H. and Schneider, S., eds.), pp. 77-88, W. deGruyter, Berlin

12 Martin, R.G. and Ames, B.N. (1961) J. Biol. Chem. 236, 1372-1379

13 Morcos, N. C., Berns, M. and Henry, W. L. (1988) Lasers Surg. Med. 8, $10-17$

14 Bryant, D.A. (1988) in Photosynthetic Light-Harvesting Systems. Organization and Function (Scheer, H. and Schneider, S., eds.), pp. 217-232, W. DeGruyter, Berlin

15 Glazer, A.N. (1985) Ann. Rev. Biophys. 14, 47-77

16 Rümbeli, R. and Zuber, H. (1988) in Photosynthetic Light-Harvesting Systems (Scheer, H. and Schneider, S., eds.), pp. 61-70, W. deGruyter, Berlin 
Index of Names

Aartsma, T.J., II.4.161, II.4.185

Aasa, R., I.3.777

Abad, M.S., II.5.231, III.13.731

Abadia, A., IV.19.757

Abadia, J., IV.19.757

Abdin, M.Z., IV.15.67

Abe, T., IV.18.467

Abramchik, L.M., III.13.819

Abresch, E., I.1.77,

Abrol, Y.P., I.3.941, III.12.597, IV.15.67

Abu-Much, E., III.9.193

Abuja, P.M., III.11.373

Adamson, E., IV.19.635, IV.19.639

Adamson, H., III.13.687, IV.19.635, IV.19.639

Adir, N., II.6.409

Ajlani, G., I.2.543, II.6.427

Åkerlund, H.-E., I.3.897, I.3.901

Albertsson, P.-A., II.5.301, II.8.831, II.8.835, II.8.839, II.8.843, II.8.923,

Albrecht, A.C., II.5.289, II.5.293

Alexander, R., IV.19.579

Allakhverdiev, S.I., I.2.379,

Alldrick, S., III.13.671

Allen, J.F., II.4.81, II.8.915, II.8.919, IV.17.333

Allen, J.P., I.1.61,

Allen, Jr., L.H., III.11.399

Allen, K.D., II.5.269, II.8.903

Alllakhverdiev, S.I., I.2.247

Althoff, G., III.9.81, III.9.133

Amesz, J., II.4.25, II.4.145, II.4.161, II.4.185, II.4.189

Amla, D.V., IV.16.143

Amory, A.M., II.6.443, IV.15.71, IV.15.75

Ampe, F., III.12.521

Anandan, S., II.5.285

Ananyev, G., I.2.247

Anbudurai, P.R., III.13.699, IV.18.545

Andersen, B., II.7.523, II.7.671, II.7.679, III.12.613

Anderson, J.M., II.8.803, II.8.935

Andersson, B., I.2.299, II.5.253, II.5.265,

II.5.273, II.6.349, II.6.423, II.7.583,

II.8.763, II.8.799, III.9.201

Andersson, P.-O., II.4.11, II.4.117

Andre, M., II.6.511, IV.17.409

Andreasson, E., II.8.831, II.8.839, II.8.843,
II.8.923

Andréasson, L.-E., I.2.527, I.3.785, III.10.319

Andreo, C.S., IV.18.537

Andrés, A.R., IV.16.251

Andrews, T.J., III.11.331

Andrianambinintsoa, S., I.2.463

Andrianova, J.E., IV.17.429, IV.19.801

Andriesse, X., III.12.533

Angerhofer, A., I.1.109, I.1.145

Apley, E., III.9.81

Apley, E.C., III.9.53, III.9.81, III.9.93

Arata, H., III.10.315

Argyroudi-Akoyunoglou, J.H., III.13.803

Ariel, R., IV.18.463

Armitage, J.P., IV.15.51

Aro, E.-M., II.6.439, II.6.459

Arrabaça, M.C., IV.19.659, IV.20.863

Asada, K., I.2.491, I.2.495, I.3.889, IV.19.619

Astier, C., I.2.543

Aula Dei, E.E., II.8.907

Aumeier, W., I.1.133, I.1.153

Avelange, M.H., IV.15.83

Avital, S., III. 9.45

Avron, M., IV.19.773

Axelsson, L., IV.18.517, IV.18.521, IV.18.525, IV.18.529, IV.18.533

Azcon-Bieto, J., IV.15.39

Baake, E., I.2.567

Baazov, D.I., IV.16.239

Babcock, G.T., I.2.239, I.2.263, I.2.483, I.2.539, I.2.643, III.12.499

Babuzhina, D.I., IV.19.801

Bachofen, R., II.4.77, IV.17.341

Bader, K.P., I.3.861, I.3.865

Badger, M.R., III.11.331

Baggoo, A.K., III.13.695

Bagley, K.A., I.1.77, I.1.81

Bahnsen, K., III.14.885

Bain, G., IV.19.705

Baker, D.N., IV.19.733

Baker, N.R., II.6.463, IV.16.259, IV.17.337,

IV.17.365, IV.17.369, IV.19.565,

IV.19.591, IV.19.679, IV.19.687,

IV.19.691, IV.20.835

Bakker, H., III.12.533 
Balakumar, T., III.13.699, IV.18.545

Balangé, A.P., III.14.873

Baldwin, B.C., IV.16.223

Ballantyne, D.J., IV.19.603

Baltscheffsky, H., II.8.763, III.9.197, III.9.201,

Baltschaffsky, M., II.8.763, III.9.197, III.9.205

Bansal, K.C., I.3.941, III.12.597

Bao, J.-S., III.11.347

Bar-Zvi, D., III.9.193

Barbato, R., I.2.339, II.6.419

Barber, J., I.2.223, I.2.279, I.2.307, I.2.327, I.2.415, I.2.419, I.2.431, I.2.435, I.2.455, I.2.611, II.6.415, II.6.515, II.6.519, II.8.715, III.12.617, III.12.637

Barends, J.P.F., I.3.693

Barillot, E., I.2.463

Barón, M., I.2.303

Barry, B.A., I.2.239, I.2.483

Bartling, D., II.5.253

Bass, W.J., II.4.73,

Bassi, R., II.5.209, II.5.249

Basu, S., IV.19.745

Baumgart, F., I.3.749,

Baumgarten, M., I.3.953

Baumgartner, B.J., III.12.423

Baur, P., II.8.827

Bauscher, M., I.1.77, I.1.81, I.1.85

Bayburt, T.H., I.3.821

Beachy, R.N., I.2.323

Béal, D., II.8.879

Beatty, J.T., III.12.453

Beauregard, M., I.2.331

Bechtel, C., I.2.355

Beck, W.F., I.3.721, I.3.817

Becker, D.W., IV.19.705

Becker, M., I.1.101, I.1.121

Beckett, P., IV.19.595

Bednárová, L., II.8.821

Beer, S., III.11.411

Beinsberger, S., III.13.775

Ben-Porath, A., IV.19.733

Bender, C., I.3.709,

Bennett, A., II.5.269

Bennett, J., II.8.747, IV.17.357

Bennoun, P., III.12.437

Bental, M., IV.19.773

Berg, S.P., I.2.671

Berger, G., I.1.89, I.2.463, III. 9.65

Bergh, S.A., IV.16.271

Bergström, H., II.4.153, II.4.173
Berliner, M.A., I.2.569,

Bernardes da Silva, A., IV.20.863

Bernarding, J., II.6.373

Bernier, F., I.3.945

Berrada, R., IV.19.777

Berry, J.A., IV.16.279, IV.19.573

Bertrand, M., III.13.787

Berzbom, R.J., III.9.57, III. 9.61

Bethenod, O., IV.19.737, IV.20.855

Betsche, T., I.6.511, IV.17.409

Betts, S.D., I.2.267, I.3.797

Betzel, Ch., II.7.547

Beuttenmüller, M., III.11.381

Bhattacharjee, R.C., III.13.695

Biaudet, P., III.9.141

Bickel-Sandkötter, S., III.9.77

Biggins, J., II.7.639, IV.17.329

Bingsmark, S., II.8.763, II.8.799

Biro, A.J., III.13.695

Bishop, N.I., I.2.507, I.3.929

Biswal, B., IV.19.813

Biswal, U.C., I.2.651

Bittersmann, E., I.2.667, II.4.165, II.4.169, II.5.297, II.7.611

Bixon, M., I.1.11,

Bizouarn, T., III.9.153

Blackwell, R.D., IV.15.15

Blankenship, R.E., I.1.121, II.4.17, II.4.37, II.4.169

Blättler, R., III.13.791

Blondel, J.D., III.14.873

Blubaugh, D.J., I.2.503

Blumenstein, S., III.9.193

Bock, C.H., II.7.619, II.7.623

Böddi, B., III.14.835

Boekema, E.J., I.2.267, I.2.375, III.9.33

Boese, S.R., IV.17.313, IV.19.643

Bogatyrenko, V.R., I.2.379,

Bogdanoff, P., III.9.217

Bogdanovic, M., III.13.683

Böger, P., IV.15.95

Bogorad, L., III.12.557

Bolhar-Nordenkampf, H.R., IV.15.31

Bonadies, J.A., I.3.709,

Bongi, G., IV.19.717

Bönigk, B., I.1.141

Booth, P.J., I.2.455, I.2.611, II. . 519

Borchard, A., III.9.97

Boschetti, A., I.2.315, II.5.257, III.13.791

Böttcher, B., III. 9.33

Bottin, H., II.7.539, II.7.631

Boucher, N., III.10.295 
Boussac, A., I.3.713

Bowden, S.J., I.2.603, I.2.411, I.2.519, I.2.551, I.3.717

Bowes, G., III.11.399

Bowlby, N.R., I.2.539, I.2.239, I.2.263, I.2.643, I.3.797

Bowyer, J., I.2.603, III.12.561, III.13.759,

Boxer, S.G., I.1.113, III.12.529

Boynton, J.E., III.12.509

Bradbeer, J.W., III.12.601, IV.16.147, IV.16.151, IV.16.155, IV.19.599

Brand, J.J., II.6.401

Brändén, R., III.11.351, III.11.371

Brandt, P., III.13.783

Brechignac, F., IV.18.433

Breidenbach, E., III.13.791

Brentel, I., III.14.843

Breton, A.M., III.12.521

Breton, J., I.1.77, I.1.81, I.1.85, I.1.89, I.2.463, I.2.467, II.4.125, II.5.305, II.5.329, II.7.599

Brettel, K., I.2.447, I.3.837, II.7.539, II.7.623, II.7.627

Breu, V., III.13.807, IV.16.287

Briantais, J.M., IV.17.365

Bricker, T.M., I.2.639, I.3.825

Britt, R.D., I.3.769,

Britton, G., II.4.53, III.14.827, IV.15.15, IV.19.587, IV.19.595

Brodt, C.A., IV.15.87

Brown, R.G., II.7.615

Brown, S., IV.15.51

Brudvig, G.W., I.3.721, I.3.817

Brugnoli, E., IV.19.741

Brune, D.C., II.4.17, II.4.37

Brunisholz, R.A., II.4.61

Bryant, D.A., II.4.1

Buchanan, B.B., IV.16.179

Büchel, C., II.8.943

Buchholz, C., III.12.621

Budde, R.J.A., IV.16.135

Buetow, D.E., III.12.549

Bukhov, N.G., I.2.559,

Bull, A.D., III.13.807

Bulté, L., III.13.715, IV.15.43

Burmester, R., IV.16.263

Burnap, R., I.2.255

Bustos, S.A., II.8.863, III.12.445

Buurmeijer, W.F., II.8.891

Buvinger, M.E., II.8.747

Bylina, E.J., I.1.53, I.1.109, I.1.149
Cabot, C., IV.19.729

Cai, X., III.13.739

Calcagno, A.M., IV.19.713

Calie, P.J., III.12.475

Callahan, F.E., II.8.733

Camilleri, P., I.2.603

Camm, E.L., I.2.659,

Cammarata, K., II.5.341

Campbell, D.A., IV.19.691

Canaani, O., IV.17.321, IV.17.325

Canvin, D.T., IV.18.513

Cao, J., I.2.515

Capo, S.F., IV.16.271

Capuano, V., II.4.101

Carlberg, S., IV.18.517, IV.18.521, IV.18.525, IV.18.529, IV.18.533

Carlson, T.J., III.12.525

Carmeli, C., III. 9.29

Carnot, L., III.12.437

Carpenter, S.D., I.2.359

Carpentier, R., I.2.343, I.2.595, II.7.691, III.10.295

Carrasco, J.L., IV.16.163

Carrillo, N., III.14.865

Carter, D.R., IV.20.859

Cashmore, A.R., III.13.779

Casimiro, A., IV.17.413

Castrillo, M., IV.19.713

Causgrove, T.P., II.4.17, II.4.37, II.5.325

Cerovic, Z.G., I.2.607, IV.16.215

Chaika, M.T., III.13.819

Chaloub, R.M., II.8.847

Chamot, D., IV.18.501

Chan, R.L., II.8.871

Chang, M.C., II.4.65, II.4.73, II.4.133

Chao, S., III.12.601

Chapados, C., I.2.343

Chapman, D.J., I.2.223, I.2.327, II.6.515

Charite, J., I.2.231, I.2.359

Chaturvedi, R., II.6.393

Cheeseman, J.M., IV.19.745, IV.20.859

Chen, G.-X., I.2.491, IV.19.619

Chen, H.-B., III.11.347

Chen, H.-Q., III.12.549

Chen, Y., III.10.287

Cheng, S.-H., IV.17.393

Cheniae, G.M., I.2.503, I.3.721

Chirino, A., I.1.61

Chittock, R., II.7.615

Cho, D.-S.C., MI.12.445

Chollet, R., IV.16.135

Chong, C.L., II.5.281 
Chongqing, T., IV.19.647

Choquet, Y., III.12.437

Chow, W.S., II.8.935

Christopher, D.A., III.12.491

Chu, C., IV.17.393

Chu, Z.-T., I.1.31,

Chueca, A., I.2.303, IV.16.163, IV.16.251

Chyaen, K., II.8.927

Chylla, R.A., I.2.383

Clark, S.E., II.5.231, III.13.731

Clarkson, J., II.8.787

Cleland, R.E., II.6.507

Clément-Métral, J.D., III.12.521

Clijsters, H., III.13.775

Clough, B.F., IV.20.859

Cmiel, E., III.13.691

Cobb, A.H., II.6.451, II.6.455

Coelho Rebelo, D., IV.20.863

Cogdell, R.J., II.4.11, II.4.61, II.4.117, II.4.121, II.4.137

Coleman, J.R., III.12.581, IV.18.455, IV.18.485, IV.18.501

Coleman, W.J., I.1.137, I.1.149, I.1.153

Connor, A.E., II.4.53,

Conrads-Strauch, J., III.12.605

Conway, A.B., I.3.829,

Cook, K.M., III.12.617

Cook, W., III.12.589

Copertino, D.W., III.12.491

Corrie, A.R., I.2.523, I.2.551, I.3.793

Cote, F., IV.17.409

Côté, R., IV.15.79

Cotton, T.M., II.8.907

Coughlan, S.J., II.7.667

Cox, A., II.4.81,

Cox, R.P., II.4.181, IV.19.761, IV.19.793

Cramer, S.P., I.3.685

Cramer, W.A., III.10.221, III.10.255, III.10.271, III.13.799

Creighton, S., I.1.31,

Cresswell, C.F., II.6.443, IV.15.71, IV.15.75

Critchley, C., II.8.899

Crofts, A.R., I.2.547, II.6.381, III.9.89, III.10.263, III.10.283, III.10.287, III.10.291

Crofts, J., I.2.391

Cronshagen, U., III.14.869

Crystall, B., I.2.455, I.2.611, II.6.519

Cunningham, Jr., F.X., IV.17.349, IV.17.353

Cupina, T., IV.20.911

Curtiss, A., III.10.307

Czernuszewicz, R., I.3.773
Dahlin, C., II.8.813

Dai, Y.-L., II.5.281, IV.19.667

Dainese, P., II.5.209, II.5.249, II.6.419

Daldal, F., III.10.231

Daley, P.F., IV.19.573

Damm, I., II.7.607, II.8.855, IV.17.405

Darrall, N.M., IV.19.599

Dau, H., IV.17.325

Dauter, Z., II.7.547

Davies, T.G.E., III.13.747

Davis, D.J., III.10.303

Day, T.A., IV.20.883

De Ciechi, P., I.2.363

De Kouchkovsky, Y., III.9.153

De Lamotte, F., IV.16.159

De Lorimer, R., II.4.1

De Paula, J.C., I.2.239, I.2.643

Deák, Z., I.3.809,

Debus, R.J., I.2.239, I.2.483, I.3.829, III.12.499

Decottignies, P., IV.16.159, IV.16.243, IV.16.247

Degani, H., IV.19.773

Deinum, G., II.4.161

Dekker, J.P., I.2.239, I.2.263, I.2.267, I.2.643, IV.16.263

Delgado, E., IV.15.39

Delrieu, M.J., I.3.833

Delucia, E.H., IV.20.883

Demeter, S., I.3.809,

Demetriou, C., I.2.411, I.2.519, I.2.551, I.3.717

Demmig-Adams, B., II.6.357

Dennenberg, R.J., IV.17.349, IV.17.353

DePamphilis, C.W., III.12.475

Depka, B., I.2.217

Deprez, J., II.5.305, II.5.329

Derose, V.J., I.3.769, I.3.789

Dexheimer, S.L., I.3.761

Di Paolo, M.L., II.5.249

Diamond, J., IV.17.413

Dian, J., II.4.205

Dianan, Y., IV.19.647

Diaz, C., IV.19.695

Dibbayawan, T., II.5.333

Dietz, K.-J., IV.19.753

Dikanov, S.A., I.2.487

Dimagno, T., I.1.109,

Diner, B., III.12.561

Diner, B.A., I.2.259, I.2.471

Ding, H.G., II.8.817

Dismukes, G.C., I.3.773, I.3.953 
Dobek, A., II.5.329

Doi, M., III.14.853

Dolan, E., I.3.781

Doldjikov, S., IV.20.915

Donner, A., I.2.591

Dörnemann, D., IV.16.287

Downie, S.R., III.12.475

Drachev, A.L. I.1.185

Dracheva, S.M., I.1.185

Drager, R.G., III.12.491

Drake, A., I.2.431

Drenkard, S., IV.19.607

Drews, G., II.4.121

Driesenaar, S., IV.17.321

Dubbs, J.M., II.4.1

Ducamp, M., II.6.511

Ducruet, J.-M., I.2.543

Dujardin, E., I.3.921, III.13.787

Dujardyn, M., II.6.491, IV.16.283

Dumont, N., III.14.849

Dupree, P., III.12.625

Durell, S., III.10.311

Durrant, J.R., I.2.415, II.6.519

Dutton, P.L., I.1.157

Dyer, T.A., III.12.461, III.12.601

Eaton-Rye, J.J., I.3.937

Eberl, U., I.1.133, I.1.153

Eckert, H.-J., II.6.373

Edelman, M., I.2.209, II.8.733

Edmondson, D.L., III.11.331

Edwards, G., IV.17.393

Eggenberger, A.L., I.2.363

Eggers, B., I.2.231, I.2.359

Ehara, T., III.12.629

Ehrenberg, A., II.6.349

Eichelmann, H., I.2.663

Eicher, S., II.4.77,

Eilenberg, H., III.11.411

Eilers, R.J., I.2.599

Eisenberg, Y., MI.12.641

El Deeb, M., I.2.239,

El Hamouri, B., IV.19.777

El-Deeb, M., I.2.483

El-Shintinawy, F., I.2.511

Elanskaya, I.V., III.12.645

Elderfield, P., III.13.665

Elich, T.D., U.8.733

Ellis, R.J., III.13.671

Enami, I., I.2.319,

Erdös, G., III.12.549

Erokhin, Yu.E., II.4.81, IV.17.345

\author{
Espie, G.S., IV.18.513 \\ Esteban, A., II.4.93, \\ Etienne, A.-L., I.2.543, II.6.427 \\ Evans, E.H., II.7.615 \\ Evans, M.B., II.4.61, \\ Evans, M.C.W., I.1.189, I.2.523, I.2.551, \\ I.2.619, I.3.793, II.7.615, II.8.919 \\ Evelo, R.G., I.2.487
}

Fagerberg, W.R., IV.17.385

Fajer, J., II.4.149

Falbel, T.G., II.5.269

Falk, G., III.9.189

Falkowski, P.G., IV.17.357, IV.20.923

Fan, L., I.1.205

Farage, P.K., IV.19.591, IV.20.835

Farchaus, J.W., I.1.161, I.1.197, I.1.201

Federman, E., IV.19.749

Feezel, L.L., I.1.181

Feher, G., I.1.39, I.1.61, I.1.77, I.1.81, I.1.141, I.1.161

Feick, R., I.1.133, I.1.137

Fenton, J.M., II.6.381

Ferguson, L., II.4.117

Femández, D., IV.19.713

Filimonov, A.A, IV.19.651

Filippova, L., IV.15.103

Fillat, M.F., II.7.663

Findlay, J.B.C., II.8.767

Fine, P.L., I.3.905

Finke, W., III. 9.57

Finkele, U., I.1.27,

Fischer, K., IV.16.203

Fischer, M.R., I.1.177, II.4.45, II.7.711, IV.17.421

Fleck, I., IV.19.695

Flügge, U.I., IV.16.203

Ford, L., IV.15.71

Forti, G., II.8.775

Fotinou, C., I.2.275

Foyer, C.H., II.6.483, II.6.491, IV.16.259, IV.16.283

Fragata, M., I.3.945

Frame, M., III.10.303

France, L.L., I.2.467

Franck, F., I.3.921, III.13.751, III.13.755, III.13.787

Frank, G., II.4.61, II.4.89, II.4.93, II.7.591

Frank, H.A., I.1.105, II.7.639

Frankel, L.K., I.2.639, I.3.825

Franzén, L.-G., II.7.591, UII.12.437

Frasch, W.D., I.3.725, I.3.781, I.3.905, 
III.9.9

Freiberg, A., II.4.157

Friedberg, D., IV.18.463

Friesner, R.A., I.1.93

Fromme, P., III. 9.15

Fronko, R.M., I.3.797

Füglistaller, P., II.4.93

Fujii, T., II.7.655

Fujimura, Y., I.2.403, I.3.957

Fujita, S., III.13.763

Fukuzawa, H., IV.18.467

Furbacher, P.N., III.10.221, III.10.271, III.13.799

Furbank, R.T., IV.18.541

Gaba, V., I.2.209,

Gabai, C., III.13.823

Gad'on, N., II.4.121

Gadal, P., IV.16.243, IV.16.247

Gal, A., II.8.779, II.8.783

Gale, J., IV.15.55

Gale, M.D., III.12.601

Galmiche, J.-M., III. 9.65

Gamble, P.E., III.12.423

Ganago, A.O., I.1.117

Gans, P., IV.15.43

Gantt, E., IV.17.321, IV.17.349, IV.17.353

Garab, G., II.7.667

Garbisu, C., II.7.699

Garcia-Véscovi, E., II.8.895

Gardeström, P., IV.15.9, IV.15.59, IV.19.805

Gardet-Salvi, L., IV.16.167

Garlaschi, F.M., II.5.313, II.5.317

Garnier, J., II.5.277

Gärtner, S., I.2.295

Gasparich, G.E., II.4.1

Gast, P., I.3.953

Gau, A.E., I.2.295

Gaugain, F., IV.17.409

Gaul, D., I.1.113

Geacintov, N.E., I.2.467, II.4.125

Geiken, B., II.6.373

Gennis, R.B., III.10.263

Genty, B., IV.16.259, IV.17.337, IV.17.365, IV.17.369

George, G.N., I.3.685

Georgi, S., III.11.385

Gepstein, S., III.11.411

Geraghty, A.M., IV.18.505

Gerhardt, V., I.3.853, I.3.857

Gerken, S., I.3.837

Gerrish, C., III.13.759
Geva, N., III.11.411

Ghanatry, J.A., II.4.73,

Ghanotakis, D.F., I.2.275, I.2.643

Ghirardi, M.L., II.8.733

Ghosh, R., II.4.77

Giacometti, G.M., I.2.339, II.6.419

Giardi, M.T., I.2.339, I.6.419

Gibbs, P., IV.17.329

Gillbro, T., II.4.11, II.4.117, II.4.181, II.5.301

Gillham, N.W., III.12.509

Gilmore, A.M., II.6.495

Gimenez, P., IV.15.95

Gimmler, H., IV.19.769, IV.19.773

Gingras, G., I.1.125

Giorgi, L.B., I.2.415, II.6.519

Girard-Bascou, J., III.12.437

Girault, G., III. 9.65

Girvin, M.E., III.10.271

Glaser, E., III.13.815

Glauser, M., II.4.89,

Gleason, F.K., IV.16.175

Gleiter, H.M., I.2.479, I.2.531

Gnanam, A., III.12.633

Godik, V.I., II.4.157

Goetze, D.C., II.7.691

Golbeck, J.H., II.6.401, II.7.531

Golden, S.S., II.6.431, II.8.863, III.12.445

Goldfeld, M.G., III.9.105, III.9.111

Goldschmidt-Clermont, M., III.12.437

Goltsev, V., IV.19.699

Gomez-Moreno, C., II.7.663

Gong, H., II.6.397

González, M.S., IV.15.47, IV.17.397

González-Murua, C., IV.19.789

Goodchild, D.J., II.8.803

Gorgé, J.L., IV.16.163, IV.16.251

Görlach, J., III.14.857

Gornicka, O., II.8.887

Gottstein, J., II.4.45,

Gough, S.P., III.12.585

Gounaris, K., I.2.223, I.2.327

Govindjee, I.2.451, I.2.459, I.2.511, I.2.515

Gräber, P., III. 9.15, III.9.33, III.9.37, III.9.217

Grandoni, P.A., III.9.145

Granok, H., I.2.367

Granot, G., IV.15.55

Gratton, E., I.2.459,

Grätzel, M., I.2.619,

Gravett, A.E., II.6.475

Gray, J.C., III.10.267, III.12.461, III.12.625 
Gray, K.A., I.1.201

Grechkin, A.N., IV.17.429

Green, B.R., I.2.659, III.12.553

Green, J.P., I.3.725, I.3.781, III.9.9

Greenberg, B.M., I.2.209,

Greer, D.H., II.6.365

Greis, J., I.1.145

Greve, B., IV.15.99

Gribenow, K., II.4.141, II.4.177

Grieve, C.M., IV.19.749

Grime, P., IV.17.361

Grimm, B., III.12.585

Grimme, L.H., II.7.607, II.8.855, IV.17.405

Grodzinski, B., IV.15.35, IV.15.79, IV.19.809

Gromet-Elhanan, Z., III. 9.45

Groom, Q.J., II.6.463

Groome, Q., IV.20.835

Gross, A., IV.16.203

Gross, E.L., III.10.299, UI.10.307, III.10.311

Gross, R., I.2.315

Grossman, A.R., III.12.541

Gruenberg, H., I.1.201

Gu, W., III.11.339

Gudowska-Nowak, E., II.4.149

Guikema, J.A., II.7.563, III.13.739

Guiles, R.D., I.3.789,

Gulyaev, B.A., I.2.427

Gunner, M.R., I.1.47,

Günther, G., IV.16.207, IV.16.211

Guo, Y.-S., II.7.695

Gustafsson, P., II.6.431, III.12.537

Guyon, D., II.5.277

Haag, E., I.2.375, I.2.479, I.3.869

Habash, D., IV.17.337

Hachtel, W., III.12.621

Haddy, A., I.3.753, I.3.777

Haehnel, W., II.7.61 1, II.7.675, II.8.739

Hagelstein, P., III.14.857

Hagemann, R., III.12.429

Haining, R.L., III.11.355

Hák, R., IV.20.899

Hala, J., II.4.205

Halevy, A.H., IV.17.417

Haley, B.E., III.11.363

Halford, N., III.11.351, III.11.371

Halkier, B.A., II.7.523

Hall, D.O., I.2.619, II.6.487, II.7.699

Hällgren, J.-E., IV.19.805

Hallick, R.B., III.12.491
Hammes, S., I.1.113

Hanaoka, T., IV.19.615

Hanke, W., III.9.83

Hansson, Ö., I.1.97, I.2.439, I.2.475, I.3.777

Hanssum, B., I.3.845

Haraux, F., III.9.141, III.9.153

Harbinson, J., IV.16.259, IV.17.365

Harmey, M.A., III.13.815

Harnett, T., I.2.291,

Harnois, J., III.10.295

Harris, D.A., III. 9.41

Harris, E.H., III.12.509

Harrison, M., IV.17.333

Hartman, F.C., III.11.343

Hase, E., III.11.391, III.12.629, III.13.735

Hatch, M.D., IV.18.541

Hauska, G., II.8.783

Hawthornthwaite, A.M., II.4.137

Hayashi, H., I.1.73,

Hayashida, N., III.13.767

Hayden, D.B., IV.19.691

He, W.-Z., I.2.431

Heber, U., IV.19.753

Heckmann, R., I.1.153

Hedrich, R., III.9.137

Hegde, U., I.2.247

Heineke, D., IV.15.1, IV.16.191

Heintze, A., III.14.857

Heldt, H.W., IV.15.1, IV.16.191, IV.16.227

Heller, B.A., II.4.65, II.4.73

Henricson, D., IV.15.59

Henry, R.L., II.7.567, III.13.739

Henrysson, T., II.8.759

Heras, L., II.6.499

Hermann, R., II.8.783

Hermoso, R., IV.16.163, IV.16.251

Herrmann, R.G., II.5.253

Herzfeld, F., III.14.869

Heupel, R., IV.15.1

Hibino, T., III.13.719

Hideg, E., I.2.623, I.3.809

Hienerwadel, R., I.1.85, I.3.841

Higashi, S.-I., I.2.403

Hiller, R.G., III.12.545

Hind, G., II.7.667

Hinrichs, W., II.7.547

Hinsch, K.-D., II.8.787

Hioki, Y., II.5.241

Hippler, M., II.7.675

Hiramatsu, H., III.13.771

Hird, S.M., III.12.461

Hirschberg, J., III.12.641 
Hisabori, T., III.9.73, III.9.169

Hiyama, T., I.2.351, II.7.587

Hladik, J., II.7.579

Hoadley, J., I.2.431

Hodges, M., II.8.875

Hodgson, R.A.J., I.2.323

Hoff, A.J., I.1.177, I.2.487, II.7.711

Hoffmann, D., I.3.853, I.3.857

Hoffmann, P., III.14.885

Hoffstädt, J., IV.16.187

Hoganson, C.W., III.10.319

Høj, P.B., II.7.523

Holt, R.E., II.8.907

Holten, D., I.1.113

Holzapfel, W., I.1.27,

Holzwarth, A.R., I.2.387, I.2.443, II.4.141, II.4.177, II.5.223, II.5.297, II.7.611

Hong, L., III.12.491

Hong, Y., II.7.667

Honig, B., I.1.47,

Hoober, J.K., III.13.723

Hopkins, R.M., II.6.451

Hoppe, P., III.14.857

Horio, T., I.2.319, III.12.517

Horovitz, A., III.12.641

Horton, P., I.2.391, I.2.399, I.2.627, I.2.631, II.6.507, IV.16.111, IV.16.219, IV.16.223, IV.17.361

Hory, F.E., III.13.695

Hoshina, S., II.7. 571

Hosoda, T., III. 9.73

Houmard, J., II.4.101

Howard, R., III.11.419

Howe, G., III.13.711

Høyer-Hansen, G., III.13.783

Huault, C., III.14.873

Hubbard, J.A.M., I.1.189, I.2.523, I.2.551, I.3.793, II.8.919

Hull, M.R., IV.19.675, IV.19.683

Humbeck, K., I.2.655

Hundal, T., II.6.423

Huner, N.P.A., II.6.467, II.6.471, III.14.861, IV.17.313, IV.19.631, IV.19.643

Hunter, C.N., II.4.153, II.4.173

Huppe, H.C., IV.16.179

Hurry, V., II.6.467, IV.17.313

Husic, H.D., IV.18.493

Ichimura, N., III.12.517

Ichimura, T., I.2.583

Ideguchi, T., III.12.517

Iglesias, A.A., IV.18.537
Iizuka, Y., IV.19.615

Ikegami, I., II.7.643

Ikeuchi, M., I.2.347, I.2.351, I.2.507

Inaba, H., I.2.623

Inagaki, J., I.2.287

Inagaki, N., III.13.763

Iñiguez, F.J., IV.19.695

Innes, J.B., I.3.817

Inoue, H., I.3.917

Inoue, K., II.7.655

Inoue, Y., I.2.347, I.2.351, I.2.507, I.3.701,

I.3.741, I.3.801, I.3.909, II.6.409

Inui, T., I.3.765

Irrgang, K.-D., I.2.355, I.2.375

Isaacson, R.A., I.1.141

Ish-Shalom, D., III.13.823, IV.19.709

Ishidsu, J.-I., II.4.49

Ishii, R., IV.20.895

Ishikawa, H., III.13.719

Ishimaru, T., II.5.309

Isogai, Y., I.3.813

Israels, R., II.4.97,

Itoh, S., I.3.813, II.7.571, II.7.643, I.7.647, II.7.651

Iwaki, M., II.7.647, II.7.651

Iwata, N., II.8.927

Jacquot, J.-P., IV.16.159, IV.16.179, IV.16.243, IV.16.247

Jagendorf, A.T., III. 9.29

Jahnke, L.S., IV.19.683

Jahns, P., I.3.881

James, M.R., III.13.699, IV.18.545

Janjic, V., IV.19.725

Janowitz, A., IV.16.211

Janssen, L.H.J., IV.20.931

Jansson, C., I.2.299, III.12.565, III.12.649

Jansson, S., III.12.537

Jawali, N., III.11.407

Jegerschöld, C., II.6.349, II.6.405

Jelic, G., III.13.683

Jenkins, C.L.D., IV.18.541

Jennings, R.C., II.5.313, II.5.317

Jensen, M.T., II.8.939

Jepsen, L.B., III.12.609, III.12.613

Jewell, C.J., I.2.569

Jewess, P., I.2.603

Jiao, J.-A., IV.15.35, IV.16.135

Jide, Z., IV.19.647

Jie, T., I.1.205

Johnson, A.M., III.12.509

Johnson, D.G., I.2.451, IV.17.361 
Johnson, L.B., IV.19.691

Joliot, A., III.10.247

Joliot, P., II.8.879, III.10.247

Jones, A.R., III.12.509

Jones, H.G., IV.20.907

Jortner, J., I.1.11,

Joshi, P.N., I.2.651

Jovanovic, L., IV.19.725

Juhler, R., IV.19.793

Junesch U., III. 9.15

Junge, W., I.3.877, I.3.881, III.9.81, III.9.97, III.9.133, III.9.137,

Jursinic, P.A., IV.17.349, IV.17.353

Juszczak, L.J., II.4.125

Kaino, N., III.12.517

Kaiser, W.M., I.1.27, IV.19.557

Kakuno, T., I.2.319, III.12.517

Kaladharan, P., IV.20.903

Källebring, B., I.1.97

Kalosaka, K., I.3.721

Kamachi, H., I.3.917

Kamo, M., IV.16.167

Kamoh, K., I.2.499

Kane, H.J., III.11.331

Kaneko, M., I.2.319,

Kannangara, C.G., III.12.585, III.13.807

Kaplan, A., IV.18.463

Kapsa, V., II.8.825

Karapetyan, N.V., I.2.559,

Karukstis, K.K., I.2.569,

Katerji, N., IV.20.855

Katoh, S., I.2.319, I.2.583, I.3.737, II.7.595, II.7.643, II.8.859

Katz-Downie, D.S., III.12.475

Kawamori, A., I.3.765

Kawamoto, K., I.3.889,

Kebire, M.S., III.13.695

Keegstra, K., III.13.799

Kellogg, E.C., I.1.129,

Kennedy, I.R., IV.15.23

Kessel, M., IV.18.463

Kessissoglou, D., I.3.709,

Kettleborough, C.A., III.11.351

Keys, A.J., III.11.371, III.11.395, III.11.351

Kim, B.-H., III.12.517

Kim, D.H., I.3.769,

Kingston-Smith, A.H., III.11.395

Kipper, M., I.2.217

Kirilovsky, D., I.2.543, II.6.427

Kirmaier, C., I.1.113

Kitamura, T., I.3.917
Kitaoka, S., IV.16.199, IV.19.615

Kitatani, Y., I.2.583

Kittsteiner, U., III.13.679

Klein, M.P., I.3.761, I.3.769, I.3.789,

Kleinherenbrink, F.A.M., II.4.145, II.4.189

Klevanik, A.V., I.1.117

Kliffen, C., IV.19.817

Klimov, V.V., I.2.247, I.2.379

Kloppstech, K., IV.19.579, IV.19.709

Klug, D.R., I.2.415, I.2.455, I.2.611, II.6.519

Klyuchareva, E.A., III.13.819

Knack, G., IV.19.579

Knobloch, K., III.9.185

Knoetzel, J., II.8.867

Knoppik, D., IV.19.607

Knorpp, C., III.13.815

Knudsen, J., II.8.939

Ko, K., III.13.779

Kobayashi, M., I.3.885, II.4.109

Kobayashi, T., I.3.913

Kobayashi, Y., II.8.927

Koch, B., П.7.523, II.7.671

Kochubey, S.M., II.8.791, II.8.795

Koenig, F., IV.17.373

Koepke, J., I.1.173

Koike, H., I.2.347, I.2.351, I.2.507

Kolaczkowski, S., I.1.129,

Kolber, Z., IV.20.923

Komenda, J., II.6.389

Komissarov, G.G., IV.15.107

Komiya, H., I.1.61,

Korstanje, L.J., II.8.755

Kotvalt, V., IV.20.899

Kotzabasis, K., III.14.881, IV.16.287

Kramer, D.M., II.6.381, III.9.89, III.10.283

Krause, G.H., II.6.479, II.6.483

Kretschmann, H., 1.3.837

Kreutz, W., I.3.841

Krieger, A., I.2.563, IV.17.307

Krishnaswamy, S., III.12.633

Krogmann, D.W., II.7.687, III.10.303

Krol, M., III.14.861, IV.17.313

Krömer, S., IV.15.1

Krstic, B., IV.20.879, IV.20.887

Kruleva, L., IV.19.699

Krupa, Z., II.6.431

Ku, M., IV.17.393

Kuang, T.-Y., I.2.335

Kugel, H., IV.19.769

Kühlbrandt, W., II.5.217

Kuhlmann, M., I.2.295

Kühne, U., III.14.869 
Kulandaivelu, G., IV.19.813

Kulikov, A.V., I.2.379,

Kumar, A., III.14.877, IV.16.275

Kumar, P.A., IV.15.67

Kunishima, N., II.7.571

Kusumoto, N., II.7.655

Kusunoki, M., I.3.801

Kutsunai, S., III.13.711

Kuwabara, T., III.13.743

Kuwata, K.T., I.2.569,

Kuznetsova. N.Yu., I.2.283

Kwa, S.L.S., I.2.279,

Laasch, H., III.9.161, IV.16.207, IV.16.211

Labahn, A., III. 9.37

Labanowski, J., III.10.311

Lachica, M., I.2.303

Lacuesta, M., IV.19.789

Lagenfelt, G., I.2.527, III.10.319

Lah, M.S., I.3.709,

Laing, W.A., II.6.365

Laisk, A., I.2.663

Lamppa, G.K., II.5.231, III.13.731

Lang, E., I.1.137, I.1.153

Lange, W., II.4.105

Lannoye, R., IV.17.425, IV.19.671, IV.19.785

Lapointe, L., IV.19.631

Larkum, A.W.D., II.5.333, II.6.385

LaRoche, J., IV.17.357

Larson, E., I.3.709,

Larsson, C., IV.18.517, IV.18.521, IV.18.525, IV.18.529, IV.18.533

Larsson, S., I.1.97

Larsson, U.K., II.5.253, II.8.759, II.8.799, II.8.835, II.8.839

Larsson-Raźnikiewicz, M., IV.16.155

Lassiter, C.B., IV.16.271

Latzko, E., IV.16.187

Lauteri, M., IV.19.741

Lavergne, J., I.3.873, I.3.893, II.8.879

Lawlor, D.W., IV.19.663

Lázaro, J.J., IV.16.163, IV.16.251

Lazova, G.N., IV.18.479

Le Marechal, P., II.8.875, IV.16.247

Lea, P.J., IV.15.15, IV.19.595

Lebedeva, N.V., III.12.645

Lechamy, A., IV.20.871

Lechner, E., IV.19.591

Lechtenberg, D., IV.16.171, IV.17.307

Lee, C.-H., I.2.387

Lee, E.H., III.11.343
Lee, P., IV.16.219

Leibl, W., II.5.305, II.5.329

Lelandais, M., II.6.483

Lemieux, S., I.2.343

Lemoine, Y., II.6.491

Lempert, U., III.13.703

Lennon, M., III.13.687

Leonhard, M., I.1.85, I.1.89, I.2.463, I.7.599

Lersch, W., I.1.137, I.1.153

Leu, S., III.12.569, III.13.811, III.13.823, III.9.193, IV.20.851

Levine, Y.K., II.5.337, II.5.345, II.8.755

Lewis, A., III. 9.29

Lewis, D., IV.16.219

Lewis, K.J., IV.15.15

Lhomme, J.-P., IV.20.855

Li, L.-R., III.11.377

Li, M., II.7.563, III.13.739

Li, S.-J., II.7.695

Li, T.-Z., I.2.335

Li, X., I.3.709,

Liese, F., III.10.279

Likhtenstein, G.I., I.2.379,

Lill, H., III. 9.1, III.9.133

Lin, C.P., I.3.953

Lin, S.-Q., I.2.335

Lindberg-Møller, B., III.12.609

Lindblom, G., III.14.843

Lindqvist, Y., III.11.323

Lingberg-Møller, B., III.12.613

Lipp, G., IV.17.421

Liu, B.-L., I.1.177

Liu, Z., IV.19.579

Ljungberg, U., II.5.253

Lloyd, J.C., III.12.601

Loach, P.A., II.4.65, II.4.69, II.4.73, II.4.133

Lobysheva, I.I., III.9.111

Lockett, C.J., I.2.411, I.2.519, I.2.551, I.3.717

Lockhart, D.J., I.1.113

Logsdon, Jr., J.M., III.12.475

Lohse, D., III.9.121

Long, S.P., II.6.463, II.6.475, IV.19.565, IV.19.591, IV.19.675, IV.19.683, IV.20.835

Longstaff, M., III.12.601

Loreto, F., IV.19.549

Lorimer, G., III.11.419

Los, D.A., III.12.593, III.12.645

Lou, S.-Q., I.2.335

Lous, E.J., I.1.61,

Lovelock, C., IV.20.859 
Lu, T., II.8.907

Lübbers, K., I.3.877

Lubitz, W., I.1.141, I.2.531

Lucero, H.A., II.8.895

Lücken, U., III. 9.33

Lühring, H., III.9.81

Luinenburg, I., III.12.581

Lundin, M., III.9.197, III.9.201

Lundqvist, T., III.11.323, III.11.419

Lutz, M., I.2.423

Møller, B.L., II.7.523, II.7.671, II.7.679

Møller, I.M., II.8.813

Macharia, J.M.N., IV.20.835

Macmillan, F., I.2.531, I.3.749

Madden, M., III.11.419

Mäenpää, P., II.5.273

Maggard, S., I.3.929,

Maguhn, J., IV.19.607

Mahajan, S., II.4.197

Mahalingham, S., III.10.263

Majeu, N., IV.18.485

Makhneva, Z.K., IV.17.345

Malinowski, H., III.13.679

Malkin, R., II.7.575, IV.17.321

Maloney, M.A., III.13.723

Malyan, A.N., III. 9.69

Mamada, K., I.2.347, I.2.351

Mamushina, N., IV.15.103

Manodori, A., III.12.541

Mäntele, W., I.1.77, I.1.81, I.1.85, I.1.89, I.2.463, I.3.841, II.4.121, II.7.599

Mar, T., I.1.125

Marani, A., IV.19.733

Marano, M.R., III.14.865

Marcus, R.A., I.1.1,

Marder, J.B., I.2.307, II.6.415

Marek, L.F., IV.18.509

Marino, J., I.3.953

Markgraf, T., IV.16.279

Marks, D.B., III.13.723

Maroc, J., II.5.277

Maróti, P., I.1.165, I.1.169

Marques da Silve, J., IV.20.863

Marrs, B.L., III.13.707

Martin, J.E., I.1.121

Maruthi Sai, P.S., II.4.197

Masojídek, J., II.6.389

Massacci, A., IV.20.907

Mathis, P., I.1.173, I.1.197, I.2.439, I.2.475, I.2.535

Mathur, P., I.3.773
Matsuoka, M., III.12.577

Matsushita, T., I.3.801

Matsuura, K., I.1.193

Matthijs, H.C.P., II.4.201, II.7.667

Mattoo, A.A., II.8.733

Mattoo, A.K., I.2.209,

Mauro, S., II.7.683, IV.17.425, IV.19.671

Mayes, S.R., III.12.617, III.12.637

Mazzola, L., I.1.113

McCauley, S.W., II.5.297

McDermott, A.E., I.3.789,

McFadden, B.A., III.11.355, III.11.359

McIntosh, L., I.2.239, I.2.483, II.12.499, III.12.649

McKiernan, M., IV.17.369

McLilley, R., IV.16.119

McMorrow, E.M., III.12.601, IV.16.147, IV.16.155

McPherson, P.H., I.1.39,

Medrano, H., IV.15.39, IV.19.729

Mei, R., I.3.729,

Melandri, B.A., III.9.85

Melis, A., I.6.435, IV.17.291

Merchant, S., III.13.711

Messinger, J., I.3.845, I.3.849

Mets, L.J., II.8.779

Metz, J.G., I.2.471

Meunier, P.C., I.2.331

Michaeli, D., II.7.555

Michaels, A., III.9.193, III.12.573, III.13.811, III.13.823, IV.20.851

Michalski, T., II.4.69,

Michel, H., I.1.173, I.3.933

Michel, H.P., II.8.747

Michel-Beyerle, M.E., I.1.11, I.1.19, I.1.133, I.1.153, I.1.137

Michelsen, B., IV.19.761

Middendorf, D., I.1.101, I.1.121

Miginiac-Maslow, M., II.8.875, IV.16.159, IV.16.243, IV.16.247

Mikami, K., III.13.767

Mikoyan, V.D., III.9.105, III.9.111

Miles, D., III.12.589

Miller, A.G., IV.18.513

Miller, M., II.4.181, IV.19.761

Millner, P.A., II.8.767, II.8.787

Mills, D., III. 9.49

Mills, W.R., IV.16.271

Mimuro, M., U.4.193, II.5.241, II.5.309

Minliang, G., IV.18.497

Miranda, M.A., IV.19.781

Mishra, R.K., IV.19.655 
Mitchell, R., II.8.739

Miyachi, S., IV.18.467

Miyao-Tokutomi, M., I.3.909,

Miziorko, H.M., IV.15.87

Mizobuchi, A., I.2.287, III.13.771

Mochizuki, Y., I.2.319,

Moenne-Loccoz, P., I.1.65, I.2.423

Moerschbacher, B., IV.19.797

Mogel, S.N., III.11.359

Mohamed, A., III.12.565

Moholt-Siebert, M., IV.19.705

Molnar, S.A., III.10.299

Monge, E., II.6.499, IV.19.765

Montañes, L., II.6.499

Montiel-Canobra, P.O., IV.16.155, IV.19.599

Moormans, R., II.8.755

Moorthy, P., III.13.699, IV.18.545

Mor, T.S., II.8.783

Morales, F., IV.19.757

Morand, L.Z., III.10.303

Morell, M.K., II.11.331

Morgun, V., IV.20.915

Morin, F., IV.17.409

Morisette, J.-C., I.2.635, I.2.647

Morishige, D.T., II.5.261

Morita, E.H., I.1.73,

Morita, M., III.10.315, IV.15.91

Morita, Y., I.3.913

Moroney, J.V., IV.18.449

Morris, A.L., I.1.181

Mörschel, E., II.4.105

Mortain-Bertrand, A., IV.17.357

Moskalenko, A.A., I.2.283, II.4.81

Moss, D.A., I.1.85

Mostowska, A., III.13.679

Moualem-Beno, D., IV.17.401

Mould, R., III.13.665

Moundib, R., IV.19.777

Mueller, M., II.5.297

Mühlenhoff, U., II.7.547

Mukerji, I., II.5.321

Mulay, M., I.2.247

Müller, H., III.9.185

Müller, M.G., II.4.177

Mullet, J.E., III.12.423

Muñoz-Rueda, A., IV.19.789

Mur, L.R., II.4.201

Murata, N., I.2.403, I.3.937, I.3.957

Mustardy, L., IV.17.349, IV.17.353

Myers, J., IV.15.63

Nabedryk, E., I.1.77, I.1.81, I.1.85, I.1.89,
I. 2.463, II.7.599

Nadanaciva, S., III. 9.41

Nagarajan, V., I.1.101, I.1.121

Nakamoto, H., IV.16.183

Nakane, H., I.2.271, I.2.311

Nalty, M.S., III.12.445

Namikawa, H., III.12.517

Napiwotzki, II.6.373

Nátr, L., IV.20.899

Neale, P.J., II.6.435

Nechushtai, R., II.7.555, III.13.661

Nedbal, L., II.6.389

Nelson, K.P., III.12.491

Nelson, N., III. 9.1

Nemoto, H., III.9.169

Nénonéné, E.K., I.3.945

Nesbakken, T., IV.20.935

Nespoulous, C., III.11.381

Neumann, K.-H., IV.16.275

Newell, W.R., I.2.279,

Newman, S.M., III.12.509

Newton, M.D., II.4.149

Nguyen, A.P., I.3.829,

Nie, G.Y., IV.19.565, IV.19.687

Niederman, R.A., II.4.33, II.4.57, II.4.129, III. 10.259

Nielsen, H.L., II.7.523

Nilsen, S., II.6.397

Nilsson, F., I.2.299,

Nishimura, M., I.3.813

Nishise, H., III.12.517

Nitschke, W., I.2.535

Nixon, P.J., I.2.259, I.2.471

Nobel, P.S., IV.20.821

Noctor, G., I.2.627

Nore, B.F., III.9.23, III.9.205

Norling, B., III.9.173

Norman, J., IV.19.705

Norris, J.R., I.1.109, I.1.181

Nothnagel, D., IV.16.187

Nugent, J.H.A. I.2.411, I.2.603, I.2.519, I.2.523, I.2.551, I.3.717

Nunes, M.A., IV.19.721

Nurmi, A., II.6.439, III.13.795, IV.17.381

Nyhus, K.J., I.2.367

Nyrén, P., III.9.23, III.9.173, III.9.177, III.9.181, III.9.197, III.9.209

Obokata, J., III.13.767

Oelze, J., II.4.41,

Oesterhelt, D., I.1.27, I.1.197, I.1.201

Oettmeier, W., I.2.591 
Offermann, K., III.12.483

Ogasawara, Y., III.12.629

Ogawa, T., III.12.525, IV.18.471

Ogiso, H., H.7.587

Ögren, E., I.3.949

Ogrodnik, A., I.1.19, I.1.133, I.1.153

Ohad, I., II.6.409, II.8.779, II.8.783, III.13.823, IV.19.709

Ohad, N., III.12.641

Ohta, Y., III.9.169

Okamura, M.Y., I.1.39, I.1.77, I.1.141, I.1.161

Okkels, J.S., II.7.523, II.7.671, II.7.679, III.12.609, III.12.613

Oku, T., II.8.927

Olivera, L.M., II.4.33

Olsen, I., II.7.523

Olson, J.M., I.4.37, II.8.939

Omata, T., III.12.525, IV.18.471

Ong, J.E., IV.20.859

Ono, T., I.3.801

Ono, T.-A., I.2.507, I.3.701, I.3.741, I.3.909

Ooms, J.J.J., II.8.883, III.9.213

Öquist, G., H.6.431, II.6.471, IV.17.313, IV.19.623

Orgen, W.L., IV.18.475

Ormerod, J., IV.20.935

Ort, D.R., III.9.145, IV.19.565

Ortiz-Lopez, A., IV.19.565

Osafune, T., III.11.391, III.12.629, III.13.735

Oswald, A., III.12.483

Ottander, C., IV.19.623

Ottersbach, P., IV.19.579

Otto, B., IV.19.579

Otto, J., III. 9.61

Ottosen, C.-O., I.3.949

Ou, K.-L., III.13.687

Ougham, H.J., III.13.747

Owens, T.G., II.5.289, II.5.293, IV.19.627

Oxborough, K., III.9.145

Oyanagi, H., I.3.801

Packer, J., III.13.759

Packer, N., III.13.687

Paddock, M.L., I.1.39, I.1.161

Padhye, S., I.2.247

Paillotin, G., II.5.329

Pais, M.S., IV.17.413

Pakrasi, H.B., I.2.291, I.2.323, I.2.363, I.2.367

Paliwal, R., I.2.371, I.2.407
Palmer, J.D., III.12.475

Palmqvist, K., IV.18.441

Pammenter, N.W., II.6.443, IV.15.71, IV.15.75, IV.20.919

Pancoska, P., II.8.821

Pankratova, S.I., IV.17.429

Panneels, P., IV.19.785

Papageorgiou, G.C., I.3.957

Parkes-Loach, P.S., II.4.65, II.4.69, II.4.73,

Pärnik, T., III.11.415

Parry, M.A.J., III.11.351, III.11.371, III.1 1.395, III.13.795

Parson, W.W., I.1.101, I.1.121, I.1.31,

Pascual, M., IV.19.695

Patzke, J., IV.19.573

Paul, K., III.11.331

Paul, M.J., IV.19.663

Paulino, C., IV.19.659

Paulsen, H., III.13.727

Pauly, S., I.3.745, I.3.837

Pecoraro, V.L., I.3.709

Pedersen, J.P., II.4.37

Pehu, E., III.13.795

Peine, G., III.14.885

Peng, D.-C., I.2.335

Penner-Hahn, J.E., I.3.797

Persson, A., II.8.923

Petersen, J., I.2.239, I.2.263, I.2.539

Peterson, R.B., I.2.395

Peyre,J.B., IV.16.159

Peyronnet, R., IV.16.159

Pfündel, E., II.6.503

Philippova, E.A., IV.19.801

Phillips, A.L., III.11.351

Phillips, J., I.2.587

Philo, J.S., I.3.953

Picaud, M., II.6.427

Pichersky, E., III.12.553

Pick, U., IV.19.773

Picorel, R., I.2.575, II.8.907

Pierce, J., UI.12.525

Pille, S., III.12.521

Pilz, I., III.11.373

Pirner, B., III.9.185

Pistorius, E.K., I.2.295

Plato, M., I.1.133, I.1.141

Plaut, Z., IV.19.749

Plesnicar, M., IV.16.215, IV.16.267

Plumley, F.G., II.5.341

Podesta, F.E., IV.18.537

Popova, L.P., IV.18.479

Popovic, R., I.2.331, I.2.635, I.2.647 
Porra, R.J., II.5.237

Porter, G., I.2.415, I.2.455, I.2.611, II.6.519

Portis, Jr., A.R., IV.16.119

Pospísilová, L., II.7.579

Post, A., IV.19.635, IV.19.639, IV.19.709

Postl, W., IV.15.31

Pramanik, A., II.8.763, III.9.197, III.9.201

Prásil, O., II.6.389

Prasil, O., II.4.205

Prat-Gay, G., IV.16.195

Preston, C., I.2.451, I.2.459, I.3.925

Priatel, J.J., III.12.453

Price, A., IV.19.595

Prince, R.C., I.3.685

Prioul, J.-L., IV.20.871

Prokhorenko, I.R., IV.17.345

Pronina, N.A., IV.18.489

Pruijsen, G., II.8.755

Pullerits, T., II.4.157

Purvis, D.J., III.10.259

Putzger, J., I.3.853, I.3.857

Pålsson, L.O., II.5.301

Quensel, J., I.3.897

Quintanar, Z.R., IV.15.47, IV.17.397

Radebaugh, C., III.12.491

Radunz, A., III.11.381, III.11.385

Raines, C.A., III.12.601

Raines, C.R., IV.19.675

Rakhimberdieva, M.G., I.2.559,

Ramazanov, Z., IV.18.441

Ramos, J.L., IV.16.163

Randolph-Anderson, B.L., III.12.509

Ranty, B., III.11.419

Rao, K.K., I.2.619,

Rapp, J.C., III.12.423

Rappaport, F., I.3.873

Raschke, K., III.9.137, IV.19.573

Rashid, A., I.2.595

Ratajczak, R., II.7.611, II.7.675, II.8.739

Raval, M.K., I.2.651

Ravnikar, P., III.12.499

Rawal, R.K., I.2.651

Rebeille, F., IV.15.43, IV.15.83

Rees, D.C., I.1.61, I.2.399, I.2.627, I.6.507

Rehm, A.M., IV.17.377

Reisener, H.J., IV.19.797

Reiss, T., III.12.649

Reith, H., II.4.201

Remy, R., II.8.875

Ren, L., III.11.373
Renger, G., I.2.355, I.2.375, I.2.479, I.2.531, I.3.749, I.3.845, I.3.849, I.3.869, II.6.373

Resta, C., II.8.775

Reubeni, J., IV.15.55

Reuter, R.A., I.2.671

Reyss, A., IV.20.871

Rhiel, E., II.4.1

Rich, P.R., III.10.239

Richards, W.R., III.13.695

Richter, M.L., II.6.377, III.9.49

Richter, P., IV.16.287

Rieß, M.H., IV.17.405

Ried, A., IV.17.377

Riens, B., IV.15.1

Rigoni, F., I.2.339, II.6.419

Rijo, P.S., IV.19.721

Rintamäki, E., III.11.367

Ripley, B.S., II.6.443

Robenek, H., II.8.739

Robert, B., I.1.65, I.2.423

Robinson, C., III.13.665

Robinson, S.P., IV.16.119

Rochaix, J.D., III.12.437

Rodrigues, M.A., II.8.851

Rodriguez, F., IV.19.781

Rodriguez-Suarez, R., IV.16.195

Roegner, M., I.2.471

Roelofs, T.A., I.2.387, I.2.443

Roepstorff, P., III.12.609

Roeske, C.A., IV.16.135, IV.18.475

Rögner, M., I.2.259, II.7.547

Römer, S., I.2.655

Rongey, S.H., I.1.161, I.1.39,

Rosengard, F., I.3.833

Rosenqvist, E., I.3.949

Rowland-Bamford, A.J., III.11.399

Roy, S., III.14.877, IV.16.275

Rubin, A.B., I.2.427

Rüdiger, W., III.13.679, III.13.703, III.13.727

Rühle, W., II.6.377, II.8.827

Rümbeli, R., II.4.93,

Rumberg, B., III.9.157, III.9.125, III.10.275, III.10.279

Rutherford, A.W., I.1.173, I.2.535, I.3.713

Ryberg, H., II.8.813, IV.18.517, IV.18.521, IV.18.525, IV.18.529, IV.18.533,

Ryberg, M., II.5.253

Setlik, I., II.6.389, II.7.563, IV.17.341

Setliková, E., II.7.563

Saadeh, S., I.3.709, 
Sadovnick, E., IV.18.463

Sacnger, W., II.7.547

Safina, N.I., IV.19.801

Saftic, D., IV.16.267

Sagara, T., I.3.885

Sahrawy, M., IV.16.163

Sainis, J.K., III.11.407

Sakac, Z., IV.20.911

Sakai, Y., III.9.205

Sakurai, H., II.7.655, II.7.707, III.9.73, III.9.169

Salih, G.F., III.9.23, MI.9.209

Salnikow, J., III.11.373

Salter, A.H., III.10.267

Salvucci, M.E., III.11.363

Samejima, M., III.12.577, IV.20.867, IV.20.895

Samson, G., I.2.635, I.2.647

Samuelsson, G., IV.18.441

Sanadze, G.A., IV.16.231, IV.16.239

Sandelius, A.S., $\mathbf{H} .8 .813$

Sandmann, G., I.2.303

Sane, P.V., II.6.393, II.6.447

Sangalli, A., II.8.775

Sano, S., I.2.495

Santhanam, R., III.13.699

Santos, C.P., II.8.851

Saric, M.R., IV.20.875, IV.20.879, IV.20.887

Sarrey, F., IV.15.83

Sasaki, H., IV.20.895

Satoh, K., I.2.271, I.2.319, I.2.439, I.2.475, I.2.499, I.2.583, III.13.763

Sauer, K., I.3.675, I.3.761, I.3.769, I.3.789, II.5.321

Savchenko, G.E., III.13.819

Saygin, Ö., I.3.837

Scaramuzzi, C.D., III.12.545

Schaafsma, T., I.2.419,

Schacfer, M.R., II.8.863, III.12.445

Schafheutle, M.E., II.7.563

Scharll, M.-F., IV.19.671

Schatz, G.H., II.4.105, II.7.611

Scheer, H., I.1.27, II.4.45, III.13.691, IV.17.421

Scheibe, R., IV.16.127

Scheidel, G., I.1.133

Scheller, H.V., II.7.523, II.7.671, III.12.609, III.12.613, II.7.679

Schenck, C., I.1.113

Scherer, S., IV.15.95

Schiff, J.A., III.13.735

Schiller, B., I.1.173
Schimkat, D., IV.16.191

Schmittmann, G., IV.19.797

Schlodder, E., I.2.447, I.3.745, I.3.837

Schmid, G.H., I.3.865, III.11.381, III.11.385

Schmidt, G.W., II.5.341

Schmitter, J.-M., IV.16.247

Schneider, G., III.11.323, III.11.419

Schneider, S., III.13.691

Schober, M., III.13.703

Schoch, S., III.13.703

Schoefs, B., III.13.755

Scholes, J.D., IV.16.219, IV.16.223, IV.17.361

Schöner, S., II.6.483

Schönfeld, M., I.1.39,

Schönknecht, G., III.9.81, III.9.137

Schröder, W.P., I.3.901

Schrubar, H., III.12.483

Schubert, K., III.10.279, III.9.125

Schultz, G., III.14.857

Schulze, E.-D., IV.20.827

Schumann, J., III.9.129, III.9.161

Schürmann, R., IV.16.167

Schwarz, B., I.2.555

Schwarz, R., IV.18.463

Schwebel-Dugue, N., IV.20.871

Scott, R.Q., I.2.623

Sealey, R.V., II.6.451, II.6.455

Searle, G., I.2.419

Seibert, M., I.2.427, I.2.451, I.2.459, I.2.507, I.2.575, I.2.619, I.3.925, II.8.907

Seidler, A., I.3.933

Seijffers, J., IV.18.463

Selman, B.R., III.9.165

Selman-Reimer, S., III.9.165

Selstam, E., III.14.843

Semenenko, V.E., III.12.593, III.12.645, IV.18.489

Sen, N., IV.20.927

Senger, H., I.2.655, III.14.881, IV.16.287

Sengupta, U.K., IV.20.891

Serra, J.L., II.7.699

Serrano, A., IV.15.95

Sesták, Z., II.8.931

Sétif, P., II.7.539, I.7.631

Sexton, T.B., III.12.423

Shackleton, J., III.13.665

Shah, N., IV.16.151

Shaolong, W., III.9.101

Sharkey, T.D., IV.19.549

Sharma, A., IV.20.891

Sharma, P.K., II.6.487 
Sharp, P.J., III.12.601

Sharp, R.R., I.3.821

Shavit, N., III.9.193

Shaw, S.L., II.5.269

Sheats, J.E., I.3.773, I.3.953

Shen, J.-R., I.3.737

Shen, Y.-K., II.8.817, IV.20.843

Shephard, M.C., IV.16.223

Sherman, L.A. 255

Sherudilo, E.G., IV.19.651

Shestakov, S.V., III.12.645

Shield, M.A., I.1.101

Shigeoka, S., IV.19.615

Shimada, K., I.1.193, II.4.49, II.4.193

Shimizu, M., III.10.315

Shin, M., II.7.659

Shinkarev, V.P., I.1.185

Shinohara, K., III.9.169, III.13.743

Shioi, Y., III.14.853

Shipton, C.A., II.6.415

Shiqing, L., IV.19.647

Shirasawa, S.-I., II.7.707

Shiver, J.W., III.13.799

Shkuropatov, A.Ya., I.1.117

Shochat, S., II.6.409

Shoham, G., II.7.555

Shoji, T., I.3.913

Shomer-Ilan, A., IV.17.401, IV.17.417

Shreve, A.P., II.5.289, II.5.293

Shuvalov, V.A., I.1.117

Shyam, R., II.6.447

Sidler, W., II.4.93, II.4.97

Siebke, K., IV.19.753

Siebzehnrübl, S., II.4.45, IV.17.421

Sieckmann, I., II.7.623

Siefermann-Harms, D., II.5.245

Siegenthaler, P.-A., III.14.849

Siegl, J., I.1.153

Siemeister, G., III.12.621

Sigrist, M., II.5.257

Silva, C.B.C., II.8.847

Silvestri, M., II.5.249

Sim, R.G., IV.20.859

Simoes, H.A., II.8.847

Simon, E., IV.19.781

Simpson, D.J., I.2.299, II.8.725, II.8.867

Sinclair, J., I.2.571

Singh, D., III.12.597

Singh, M., II.6.393

Singhal, G.S., I.2.371, I.2.407, IV.19.655

Sinning, I., I.1.173

Sithole, I., I.2.239, I.2.483, III.12.499
Sivaguru, M., III.13.699, IV.18.545

Sivak, M., IV.19.789

Sivaraja, M., I.3.953

Skála, L., II.8.825

Sleator, N.J., III.12.491

Slooten, L., III.9.149

Small, C.L., III.11.355

Smeekens, S., III.12.573

Smith, A.J., III.13.807

Smith, H.B., III.11.343

Smith, S., II.7.687

Smith, U., I.1.181

Smith, V.R., IV.20.919

Smith, W.K., IV.20.883

Snel, J.F.H., II.8.911

Snyder, W., II.4.1

Sofrova, D., II.7.579

Somersalo, S., II.6.479

Soncini, F.C., II.8.871

Sonoike, K., II.7.595

Sopory, S.K., I.2.209, II.8.733

Spalding, M.H., IV.18.505, IV.18.509

Spangfort, M., II.5.253, II.5.265

Sparrow, R., II.7.615

Specht, S., I.2.295

Speer, R., I.1.145

Speirs, J., III.12.545

Spence, S.M., I.2.571

Spillmann, A., II.8.739

Staehelin, L.A., II.5.269, II.8.903

Stankovic, Z., IV.20.875, IV.20.87'9, IV.20.887

Steck, K., II.4.121

Stehlik, D., II.7.619, II.7.623

Steinmetz, D., II.7.607, II.8.855

Steinmüller, K., III.12.557

Steup, M., III.12.605, IV.15.99

Stevenson, J.K., III.12.491

Stilz, H.U., I.27,

Stirewalt, V.L., II.4.1

Stocker, J.W., III.12.529

Stolz, B., II.8.809

Strasser, R.J., I.2.555, I.2.567, I.2.61.5, II.6.503

Strelow, F., III.9.125, III.9.157

Streubel, M., III.12.483

Streusand, V.J., I.2.599,

Strid, A., III.9.23, III.9.173, III.9.177, III.9.181

Strotmann, H., III.9.121, III.9.141

Struck, A., III.13.691

Strümper, P., III.9.77 
Struve, W.S., II.5.325

Strzałka, K., II.8.887

Sturgis, J.N., II.4.57

Styring, S., I.6.349, II.6.405, II.6.423

Sugiura, M., III.12.469, III.13.767

Sumida, S., III.11.391

Sundblad, L.-G., IV.18.441

Sundby, C., II.8.759

Sundström, V., II.4.153, II.4.173

Suter, F., II.4.97

Sutton, B.J., IV.16.147

Suzuki, E., IV.18.467

Suzuki, K., II.7.587, IV.18.505, IV.18.509

Suzuki, M., I.3.801

Svendsen, I., II.7.679

Svensson, P., II.5.301, II.8.831, II.8.839, II.8.923

Szczepaniak, A., III.10.221, III.10.255

Tae, G.-S., III.10.221

Taguchi, A.K., III.12.529

Taira, T., IV.16.199

Takabe, T., III.13.719

Takahashi, E., I.1.169

Takahashi, M., I.2.495, I.3.757

Takahashi, Y., I.2.311, I.2.499

Takaichi, S., II.4.49,

Takamiya, K.-I., III.10.315, IV.15.91

Takano, Y., II.7.587

Takeda, T., IV.19.615

Takenaka, A., IV.17.299

Takio, K., I.2.347

Tamai, N., II.4.193, II.5.309

Tamura, N., I.3.917

Tandeau de Marsac, N., II.4.101

Tang, C.-Q., I.2.335

Tanguay, N.A., I.7.639

Taoka, S., I.2.547

Tappermann, P., I.1.137

Tarchevsky, I.A., IV.17.429, IV.19.801

Tardieu, F., IV.19.737

Tasumi, M., I.1.73,

Taylor, M., III.13.759

Tchuinmogne, S.J., III.14.873

Telfer, A., I.2.419, I.2.431, I.2.435

Terakado, K., II.7.587

Terao, T., II.8.859

Terashima, I., IV.17.299

Tetenkin, V.L., I.2.427

Theiler, R., II.4.129, III.10.259

Thibodeau, D., I.1.85

Thiel, T., I.2.291
Thomson, W.W., II.8.803

Thomber, J.P., II.5.261, II.5.285

Thurnauer, M.C., I.1.181

Tiede, D.M., I.1.129,

Timmerhaus, M., II.8.771

Timmins, P.A., II.7.563

Timpmann, K., II.4.157

Ting, C.S., IV.19.627

Tingyun, K., IV.19.647

Titov, A.F., IV.19.651

Tjus, S., II.7.583

Todd, C., III.12.561

Tokito, M.K., III.10.231

Toner, W., II.7.615

Tongzhu, L., IV.19.647

Torgersen, Y., IV.20.935

Toropygina, O.A., II.4.81

Tourikas, C., III.9.173

Tran-Anh, T., III.9.125, III.9.157

Trautman, J.K., II.5.289, II.5.293

Trebst, A., I.2.217

Tremolieres, A., II.5.277

Trissl, H.-W., II.5.305, II.5.329

Trujillo, I., IV.19.713

Tschopp, P., II.4.77,

Tsinoremas, N.F., II.8.919

Tso, J., I.3.953

Tsugita, A., IV.16.167

Tsujita, M.J., IV.15.35

Turina, M.P., III.9.85

Tyystjärvi, E., II.6.439, II.6.459

Tzinas, G., III.13.803

Uehara, A., I.3.801

Uehara, K., II.5.241

Ueno, O., IV.20.867

Ullrich, J., I.1.145

Urbanová, M., II.8.821

Usuda, H., IV.16.199, IV.16.255

Uusitalo, J., IV.18.517, IV.18.521, IV.18.525, IV.18.529, IV.18.533

Vacek, K., II.4.205, II.8.821, II.8.825

Vacha, M., II.4.205

Vadell, J., IV.19.729

Val, J., II.6.499, IV.19.679, IV.19.765

Valcke, R., III.13.775

Valle, E.M., IV.16.227

Vallejos, R.H., II.8.871

Van 't Veld, A.A., II.8.755

Van Amerongen, H., I.2.279, II.4.113

Van Arkel, G., III.12.533 
Van Berkel, J., III.12.605

Van de Meent, E.J., II.4.145

Van de Ven, M., I.2.459,

Van der Est, A.J., II.7.619, II.7.623

Van der Staay, G.W.M., II.4.201

Van der Vies, S., III.13.671

Van Ginkel, G., M.5.337, II.5.345, II.8.755

Van Gorkom, H.J., I.3.693, I.3.805

Van Grondelle, R., I.2.279, II.4.113, II.4.133, II.4.137, II.4.141, II.4.153, II.4.161, II.4.173

Van Gurp, M., II.4.113, II.5.337, II.5.345

Van Haeringen, B., II.4.113, II.4.141

Van Hasselt, P.R., IV.17.389, IV.20.931

Van Hove, L.W.A., IV.19.611

Van Ieperen, W., II.8.911

Van Kan, P.J.M., II.4.185

Van Kooten, O., IV.19.611

Van Leeuwen, P.J., I.3.693

Van Loven, K., UI.13.775

Van Mieghem, F.J.E., I.2.535

Van Mourik, F., I.2.279, II.4.113, II.4.133, II.4.137, II.4.141

Van Onckelen, H., III.13.775

Van Vliet, P.H., III.9.213

Van Wijk, K.J., IV.17.389

Van Zandvoort, M., II.8.755

Vandeloise, R., II.7.683

Vandenbranden, S., III.9.149

Vander Donckt, E., II.7.683

Vänngård, T., I.3.749, I.3.753, III.10.319

Vass, I., I.2.223, I.3.809

Vassey, T.L., IV.19.549

Vater, J., I.2.355, III.11.373

Vázquez, M.J., IV.15.47, IV.17.397

Velasco, G.R., IV.15.47, IV.17.397

Veljovic, S., IV.16.215, IV.19.725

Venturoli, G., III.9.85

Vermaas, W., I.2.231, I.2.359, I.2.667

Vermeglio, A., III.10.247

Vernotte, C., I.2.543

Versluis, W., II.8.883

Vesk, M., II.5.333

Vidal, D., IV.19.781

Viil, J., III.11.415

Violette, C.A., I.1.105

Virgin, I., II.6.349, II.6.423, III.12.537

Virolainen, A.A., IV.19.651

Visscher, K.J., II.4.153

Visschers, R.W., II.4.133

Vitseva, O.I., III. 9.69

Vivekanandan, M., IV.20.903
Volk, M., I.1.133, I.1.153

Volovik, O.I., II.8.791, II.8.795

Volz, E., III.10.275

Von Heijne, G., III.13.653

Von Schütz, J.U., I.1.145

Von Wettstein, D., III.13.783

Vonk, C.A., II.4.137

Vorst, O., III.12.573

Vos, M.H., I.3.693, I.3.805

Voss, B., IV.16.171

Vredenberg, W.J., II.8.883, II.8.891, II.8.911, III.9.213, IV.19.611

Wachtveitl, J., I.1.197, I.1.201

Wacker, T., II.4.121

Wacker, U., I.3.869,

Wada, K., II.7.571

Waggoner, C.M., I.3.739,

Wagner, R., III. 9.53, III.9.81, II.9.93

Waldburger-Schlapp, M., IV.17.341

Waldo, G.S., I.3.797

Walker, D.A., II.6.507

Walmsley, J., III.13.687

Walter, G., III.14.885

Walters, R.G., I.2.631

Walz, D., II.8.809

Wälzlein, G., I.2.295

Wan, J., II.7.695

Wang, J., II.4.17

Wang, K.-B., II.5.281, IV.19.667

Wang, W.Q., I.6.515

Wang, Z., III.10.291

Warden, J.T., II.7.635

Warncke, K., I.1.157

Warshel, A., I.1.31,

Wasielewski, M.R., I.1.129, I.2.451

Watanabe, T., I.3.885, II.4.109

Webb, R., I.2.255

Webber, A.N., II.7.575, III.12.461

Wedel, N., II.5.253

Weiler, E.W., IV.15.99

Weinberg, D., III.13.811

Weinzettel, A., II.8.827

Weis, E., I.2.563, II.8.771, IV.16.171, IV.17.307

Weisbeek, P., III.12.533, III.12.573

Weiss, C., IV.19.769

Weiss, D., IV.17.417

Weiss, E., I.2.663

Weiss, U., IV.19.769

Wellington, C.L., III.12.453

Welte, W., II.4.121, II.7.563 
Wen, H., II.7.699

Weng, J.-M., III.11.347

Westerhuis, W.H.J., II.4.129

Westhoff, P., III.12.483

Whelan, J., III.13.815

White, I.R., II.8.767

White, L.A., I.2.671

Whitelegge, J., I.2.603

Whitmarsh, J., I.2.383

Widholm, J.M., IV.18.475

Widler, W., II.4.89

Wigge, B., IV.15.9, IV.15.59

Wild, A., II.6.377, II.8.827

Wilhelm, C., II.4.105, II.8.943

Wilhelmová, N., II.8.931

Willey, D.L., III.12.461

Williams, J.G.K., IV.18.471

Williams, J.P., IV.17.313

Williams, M.L., II.6.451, II.6.455

Williamson, D.L., I.2.575

Wingsle, G., IV.19.805

Winterberg, A., IV.19.785

Witt, H.T., I.3.745, I.3.837, II.7.547

Witt, I., II.7.547

Wolf, H.C., I.1.145

Wolfe, D.W., IV.19.627

Wollman, E., IV.16.159

Wollman, F.-A., III.13.715, IV.15.43

Wolosiuk, R.A., IV.16.195

Won, Y., I.1.93

Wonders, J.H.A.M., II.8.891

Wood, W.F., II.6.385

Woodbury, N.W., II.4.165, II.4.169, III.12.529

Woodrow, L., IV.19.809

Wraight, C.A., I.1.165, I.1.169

Wright, D.P., IV.16.223

Wu, B., II.5.277

Wu, G.-Y., III.11.339, III.11.403

Wu, X.-Y., III.11.339, III.11.403

Wünschmann, G., II.6.401

Wydrzynski, T., I.3.749

Wynn, R.M., II.7.575

Xu, C.-H., II.5.281, IV.19.667

Xu, R.-B., III.11.377

Xu, Y.-N., II.7.695, III.11.403

Yachandra, V.K., I.3.769, I.3.789

Yalovsky, S., III.13.661

Yamamoto, H.Y., II.6.495

Yamamoto, K., II.8.927
Yamamoto, Y., I.2.287, III.13.771

Yamashita, J., III.12.517

Yamashita, T., I.3.913

Yamazaki, I., II.4.193, II.5.309

Yanai, N., II.7.587

Yang, D.H., IV.19.667

Yang, L., I.1.177

Yang, S., II.5.325

Yang, Y., IV.15.99

Yano, K., IV.16.167

Yarin, A.U., IV.17.429

Yeh, S., I.3.821

Yepiz-Plascencia, G., III.12.491

Yerkes, C.T., II.6.381

Ying, W.-L., II.7.695

Yocum, C.F., I.2.239, I.2.263, I.2.267, I.2.539, I.2.643, I.3.729, I.3.739, I.3.797

Yokota, A., III.11.391, IV.16.199, IV.19.615

Yokoyama, E.-I., II.7.655

Yordanov, I.T., IV.19.699

Yoshihira, T., II.8.927

Young, A.J., IV.15.15, IV.19.587, IV.19.595

Young, D.A., III.13.707

Youvan, D.C., I.1.53, I.1.137, I.1.149, I.1.153

Youze, L., III.9.101

Yu, S.-G., II.8.835, II.8.839, II.8.843

Yun, C.-H., III.10.263

Yushu, Z., I.1.205

Yuzhu, G., IV.18.497

Zatezalo, S., IV.20.875, IV.20.887, IV.20.879

Zeroni, M., IV.15.55

Zhang, G.Z., II.5.281

Zhang, Q.-D., I.2.335

Zhang, Z.H., III.12.637

Zhao, F.H., IV.19.667

Zhao, J., II.6.401

Zharmukhamedov, S.K., I.2.247

Zhenglian, Z., I.1.205

Zhengping, M., III.9.101

Zhenlin, Z., IV.18.497

Zhong, W., IV.18.497

Zhou, F.-H., II.5.281

Zhou, J., II.4.1

Zhuravel, T.T., II.8.795

Ziegler-Jöns, A., IV.19.607

Zilber, A., II.7.575

Zilberstein, A., III.11.411

Zilinskas, B.A., II.4.125

Zimmermann, J.-L., I.3.713, I.3.789 
Zinth, W., I.1.27,

Znak, N., IV.20.915

Zuber, H., II.4.61, II.4.89, II.4.93, II.4.97, II.7.591

Zubkova, H., IV.15.103

Zucchelli, G., II.5.313, II.5.317

Zuo, B.-Y., I.2.335 